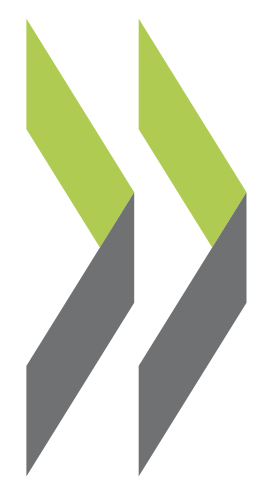

OECD Economics Department Working Papers No. 453

Getting the Most Out

of Public Sector

Isabelle Joumard

Decentralisation in Mexico 
ECONOMICS DEPARTMENT

GETTING THE MOST OUT OF PUBLIC SECTOR DECENTRALISATION IN MEXICO ECONOMICS DEPARTMENT WORKING PAPERS, NO. 453

by

Isabelle Joumard

All Economics Department Working Papers are now available through OECD's Internet web site at http://www.oecd.org/eco. 


\section{TABLE OF CONTENTS}

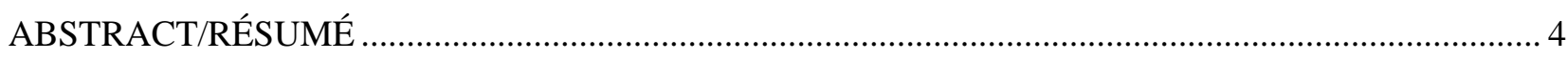

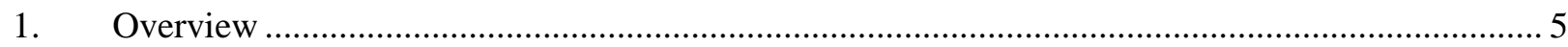

2. Forces shaping fiscal relations across levels of government ...................................................... 6

2.1 The democratisation process has spurred demands for more powers at a sub-national level..... 6

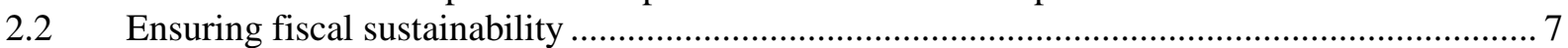

2.3 Addressing sizeable disparities in regional development levels .......................................... 7

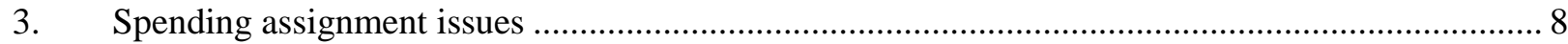

3.1 Although limited in scope, decentralisation has spurred innovations in management ........... 10

3.2 Several factors have limited effective autonomy and accountability at a sub-national level.... 10

3.3 The design of earmarked grants perpetuates regional disparities, ...................................... 13

$3.4 \quad \ldots$ and earmarked grants create adverse incentives for a cost-effective delivery of public

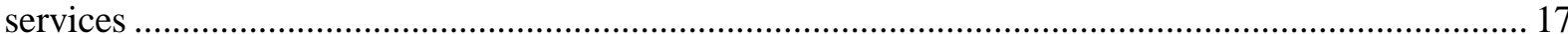

4. Issues in funding arrangements for sub-national governments .............................................. 18

4.1 Tax revenues account for a marginal share of sub-national governments' financial resources 18

4.1.1 Sub-national governments have few taxing powers and hardly use those they have......... 18

4.1.2 Raising sub-national governments' own taxes has met serious constraints......................... 22

4.2 Revenue-sharing arrangement: a limited equalisation content ............................................ 26

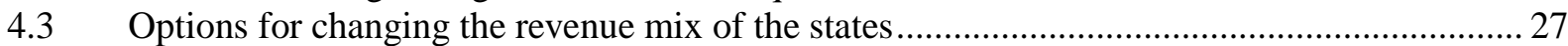

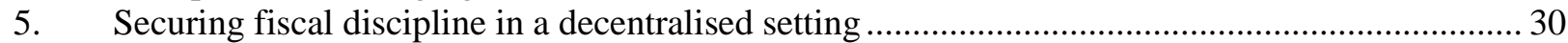

5.1 The volatility of sub-national government revenues distorts their spending behaviour ............ 30

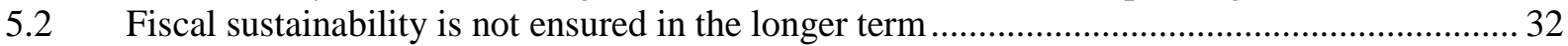

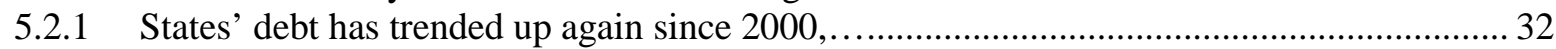

5.2.2 $\ldots$ and mechanisms to contain it have not been implemented in all the states ..................... 34

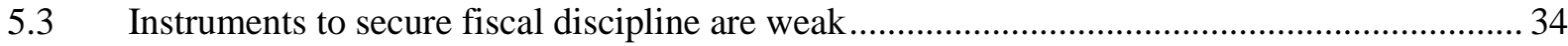

5.3.1 Fiscal rules imposed on sub-national governments are lenient............................................ 34

5.3.2 Recent reforms to strengthen the disciplining role of market mechanisms....................... 36

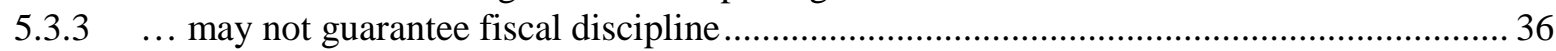

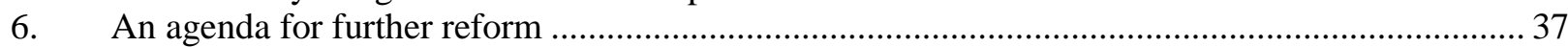

6.1 Accompany greater sub-national government autonomy on the spending side by more

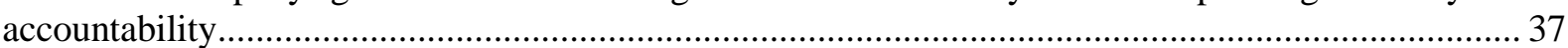

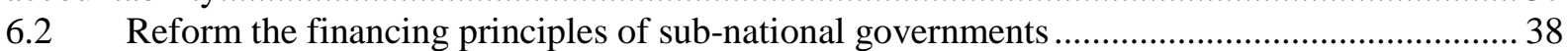

6.3 Maintain a stabilisation role for fiscal policy and promote fiscal sustainability....................... 39

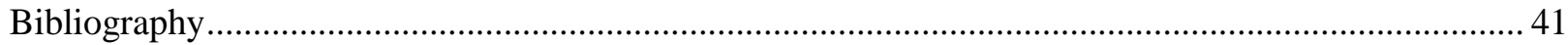




\section{Boxes}

Box 1. The sharing of responsibilities across levels of government for key public services ..................... 9 Box 2. Main earmarked grants: criteria used to set the amount and to distribute them across sub-national

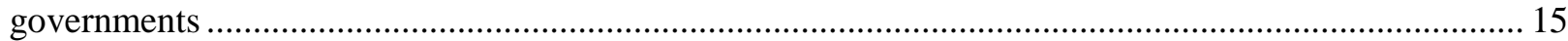

Box 3. The sharing of taxing powers and revenues across government levels since the 1980s............... 21

Box 4. Main recent tax reforms to increase states' taxing powers since the mid-1990s ......................... 25

Box 5. Experience with decentralised VAT in Canada and within the EU area .................................... 29

Box 6. Master trust arrangements to facilitate sub-national government access to financial markets...... 37

Box 7. Recommendations for improving fiscal relations across levels of government ........................... 40

\section{Tables}

1. Sub-national government taxing powers in selected OECD countries

2. Main own taxes of the states

3. Strategies for ensuring fiscal discipline: fiscal rules and guarantees in selected countries

\section{Figures}

1. Sub-national governments' share in general revenues and expenditure

2. Regional dispersion in GDP per capita in OECD countries: an international and time perspective

3. Public sector employment in perspective

4. Distribution of the main earmarked grants across sub-national governments

5. Main earmarked grants to sub-national governments

6. Sub-national financial resources

7. Recurrent taxes on immovable property in OECD countries

8. Per capita transfers received by states through the revenue-sharing scheme

9. Volatility in federal transfers received by sub-national governments

10. States' liabilities 


\title{
ABSTRACT/RÉSUMÉ \\ Getting the most out of public sector decentralisation in Mexico
}

\begin{abstract}
Enhanced autonomy of sub-national governments has spurred innovative management. Spending assignments across levels of government, however, often overlap and/or are not yet fully understood by most citizens. Sub-national governments' accountability is further reduced by the heavy reliance on federal transfers, as opposed to own-revenues (taxes and user fees). In addition, the use of federal transfers as collateral for states' borrowing potentially undermines the role of financial markets in disciplining fiscal behaviour. Getting the most out of decentralisation would thus require a national agreement clarifying responsibilities for each level of government. Improving sub-national governments' incentives in delivering cost-effective public services would further require improving the quality of information on actual spending and outcomes, raising the volume of their own taxes and reforming the grant systems. Decentralisation should also be more consistent with the aim of improving interregional equity in obtaining access to core public services.
\end{abstract}

JEL classification: $\mathrm{H} 1, \mathrm{H} 2, \mathrm{H} 4, \mathrm{H} 5, \mathrm{H} 7, \mathrm{H} 77$

Keywords: fiscal federalism, sub-national government; sub-national taxes; intergovernmental grants, fiscal rules, fiscal discipline, Mexico.

This Working Paper relates to the 2005 OECD Economic Survey of Mexico (www.oecd.org/eco/surveys/mexico).

$* * * * * * *$

\section{Optimiser l'impact de la décentralisation au Mexique}

L'autonomie renforcée des collectivités territoriales pour la gestion des services publics a permis le développement d'innovations intéressantes. Les responsabilités pour un certain nombre de programmes publics du gouvernement fédéral, des états et des communes se recoupent néanmoins fréquemment et/ou ne sont pas pleinement comprises par la plupart des citoyens. Le rôle prépondérant des transferts fédéraux dans le budget des collectivités territoriales, par opposition aux ressources propres issues de redevances ou d'impôts locaux, n'incite pas les collectivités territoriales à se montrer redevables envers les citoyens. L'utilisation des transferts fédéraux comme garantie pour les emprunts des états nuit à la possibilité d'une discipline budgétaire dictée par les marchés financiers. Pour optimiser l'impact de la décentralisation sur l'économie, il faudrait un accord national clarifiant les responsabilités de chacune des administrations publiques dans la gestion des programmes publics. Les incitations des collectivités territoriales à offrir des services publics répondant mieux aux besoins des citoyens devraient être aussi renforcées en améliorant la qualité des informations sur les dépenses effectives et leurs résultats, en donnant aux impôts locaux un rôle accru et en réformant le système des transferts intergouvernementaux. Il est aussi souhaitable que la décentralisation soit conçue en vue d'une plus grande équité entre les régions pour l'accès aux services publics de base.

Classification JEL: H1, H2, H4, H5, H7, H77

Mots clés: fédéralisme financier, collectivités territoriales, impôts locaux, transferts intergouvernementaux, règles budgétaires, discipline budgétaire, Mexique

Ce Document de travail se rapporte à l'Etude économique de l'OCDE du Mexique 2005 (www.oecd.org/eco/etudes/mexique).

\section{Copyright OECD, 2005}

Applications for permission to reproduce or translate all, or part of, this material should be made to: Head of Publications Service, OECD, 2 rue André-Pascal, 75775 Paris Cédex 16, France. 
ECO/WKP(2005)40

\title{
GETTING THE MOST OUT OF PUBLIC SECTOR DECENTRALISATION IN MEXICO
}

\author{
Isabelle Joumard $^{1}$
}

\section{Overview}

1. The recent devolution of spending responsibilities to sub-national governments could potentially benefit the citizens in that local authorities are better placed to judge relative priorities and means of satisfying them. But the current system does have flaws. Most importantly, there is a profound imbalance between sub-national governments' spending and financing autonomy. Sub-national governments now account for a high share of public spending, with significant autonomy to run into deficit and debt but the tax system is still very centralised (Figure 1). In addition:

- Although devolution has given rise to fruitful innovations in managing public services, sub-national governments still lack some flexibility and incentives to provide public services in a cost-effective manner. Overlapping responsibilities between jurisdictions and the design of earmarked grants may also be leading to sub-optimal spending and/or quality control in some areas.

- The system of federal government transfers to sub-national governments has largely perpetuated disparities in access to core public services across jurisdictions. Earmarked grants received by each state largely reflect actual spending at the time of the decentralisation, which tended to be higher in richer states. Likewise, the degree of fiscal equalisation achieved through the revenue-sharing system is limited since this was designed to compensate states for relinquishing their taxing powers to the federal government - thus richer and oil-producing states receive more, on a per capita basis, than poorer ones.

- Information on the use of financial resources by sub-national governments is scant, reflecting a lack of auditing co-ordination between federal and sub-national governments, as well as a still too limited role of auditing bodies at the sub-national government level.

- States and municipalities have few political incentives to raise more tax revenue even though public spending in some areas is sub-optimal.

- State and local government finances are volatile. Carry-over provisions of unspent transfers are limited, leading to inefficient spending with the risk of a ratchet effect.

- Rather loose fiscal rules and ineffective market mechanisms contribute to hamper fiscal discipline, with the unfortunate precedent of the federal government bailing out sub-national governments.

1. The paper was originally produced for the 2005 OECD Economic Survey of Mexico, published in September 2005 under the authority of the Economic and Development Review Committee of the OECD. It has also benefited from discussion with numerous Mexican experts, including from the federal government and the states of Chiapas and Sonora. I am indebted to Bénédicte Larre, Andrew Dean, Jorgen Elmeskov, Christopher Heady, Robert Price, Sylvie Toly, Nick Vanston, Stéphanie Guichard, Carla Belmont and many OECD colleagues for valuable comments on earlier drafts or for sharing their knowledge. I am also grateful to Hervé Bource and Veronica Humi for secretarial assistance. 
2. This paper identifies policy options to deal with these issues and improve fiscal relations across levels of government. The first section reviews economic and political forces shaping the decentralisation process. The following three sections present the main issues related to current spending, revenue assignments and existing instruments to secure fiscal discipline. The final section provides conclusions and policy recommendations.

Figure 1. Sub-national governments' share in general government revenues and expenditure Per cent, 2003 (1)

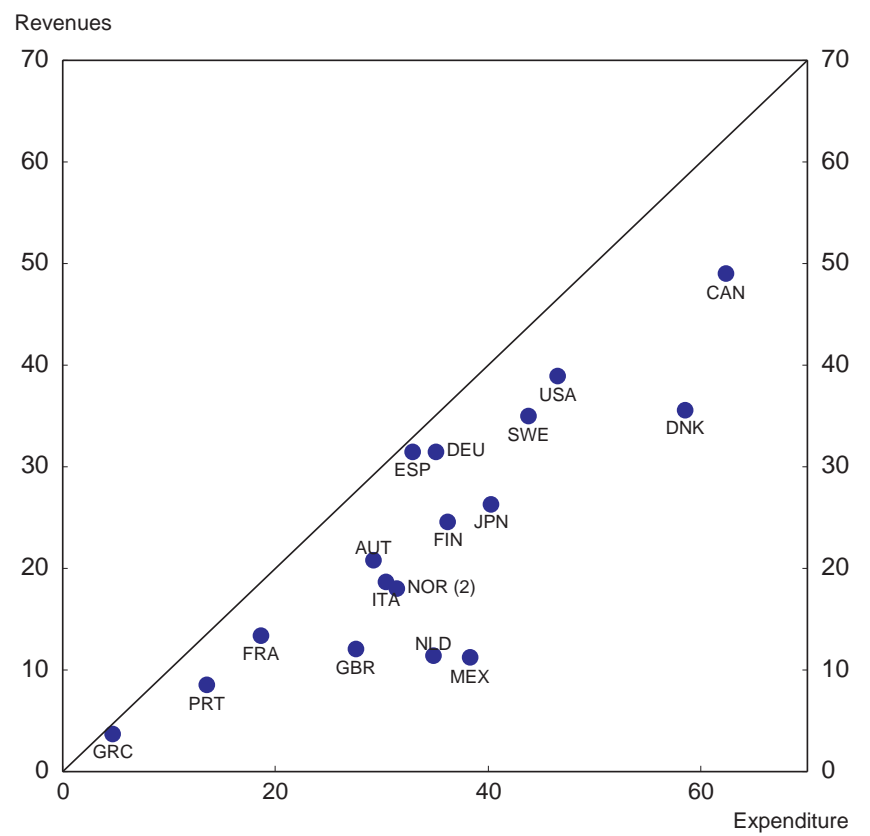

1. Or latest year available: 2000 for Japan, 2002 for Denmark and Mexico. Revenues include direct and indirect taxes as well as non-tax revenues received by regional and local governments and are expressed as a share of revenues received by the general government. Expenditure corresponds to total expenditure by regional and local governments expressed as a share of general government expenditure. Transfers between governments are netted out.

2. Mainland only. Data exclude revenues from oil production.

Source: OECD, National Accounts; Statistics Norway; Statistics Canada; US Bureau of Economic Analysis.

\section{Forces shaping fiscal relations across levels of government}

\subsection{The democratisation process has spurred demands for more powers at a sub-national level}

3. For most of the past 70 years, the Institutional Revolutionary Party, the PRI, had the monopoly of presidential power, a majority in Congress and among state Governors. It began to lose its monopoly in the late 1990s. The new political situation, with president and state governors but also state governors and mayors being affiliated to different political parties in an increasing number of cases, has reinforced demands for more autonomy at the sub-national government level. Congress also plays a more active role than hitherto in the budget process, for example in being able to increase transfers to sub-national governments (Webb and González, 2004). ${ }^{2}$

2. The Mexican bicameral Congress is made of the Senate - each state is equally represented by three senators, in addition to 32 proportional seats divided in 5 circumscriptions - and the Chamber of Deputies. 
ECO/WKP(2005)40

\subsection{Ensuring fiscal sustainability}

4. Although sub-national governments have received higher federal transfers since the early 2000s, their debt has again embarked on a rising path, although admittedly from a low level. Estimates on implicit liabilities associated with states' pension systems for public employees are also worrisome and reforms to put these systems on a sounder financial footing have not been particularly ambitious. The generalised bail-out in the wake of the 1995 peso crisis, combined with the lack of clarity in each government tier's responsibilities for delivering core public goods, may raise expectations among lenders that the federal government will come to the rescue of states in financial difficulties. At this juncture, it is therefore of paramount importance that sub-national government budget constraints are hardened and sub-national government incentives to raise their own tax revenues are strengthened.

5. The relatively favourable fiscal and monetary environment conceals tensions about long-term fiscal sustainability. Although on the rise, interest rates are currently low by historical standards, reducing the current cost of borrowing for sub-national governments. On the fiscal side, not only has the new political set-up allowed sub-national governments to capture a growing share of the country's revenues but the overall pool of national public revenues has risen as oil prices have soared. An increase in financial resources is necessary to meet development spending needs in most deprived areas. In particular, implementing health care coverage for the non-insured population (Seguro Popular) is expected to cost about two-thirds of a percentage point of GDP per year by 2010. Likewise, additional resources are needed in the basic education sector managed by the states so as to improve enrolment rates and educational outcomes (Guichard, 2005). However, financing permanent spending through revenues which are currently high but may not necessarily remain permanently so may ultimately threaten fiscal sustainability.

\subsection{Addressing sizeable disparities in regional development levels}

6. Disparities in development levels across jurisdictions are high by OECD standards and have not changed much over the past decades (Figure 2). ${ }^{3}$ Endowments in basic public services (e.g. for health care services, water provision and electricity) also differ considerably in Mexico and are inversely correlated with measured social and economic exclusion. The process of trade liberalisation initiated in the mid-1980s has exacerbated regional disparities, since those states initially endowed with higher levels of human and infrastructure capital have been able to attract foreign investment inflows and exploit agglomeration effects, while the proximity to the US market has been another key advantage for Northern states. ${ }^{4}$ These disparities in regional development levels complicate the choice of a tax base to be used locally, since some bases are distributed across regions more unequally than others. Addressing them further calls for a strengthening of fiscal equalisation schemes across jurisdictions.

3 The concentration of oil activity has an important influence on GDP per capita. As an example, Campeche has one of the highest GDP per capita but without oil revenues would have one of the lowest.

4. Evidence on the differentiated impact of the opening up to international trade and capital flows across the Mexican states is provided by many authors, including Rodríguez and Sánchez-Reaza (2002), Chiquiar Cikurel (2002) and Mendoza Cota and Martínez (2001). 
Figure 2. Regional dispersion in GDP per capita in OECD countries: an international and time perspective
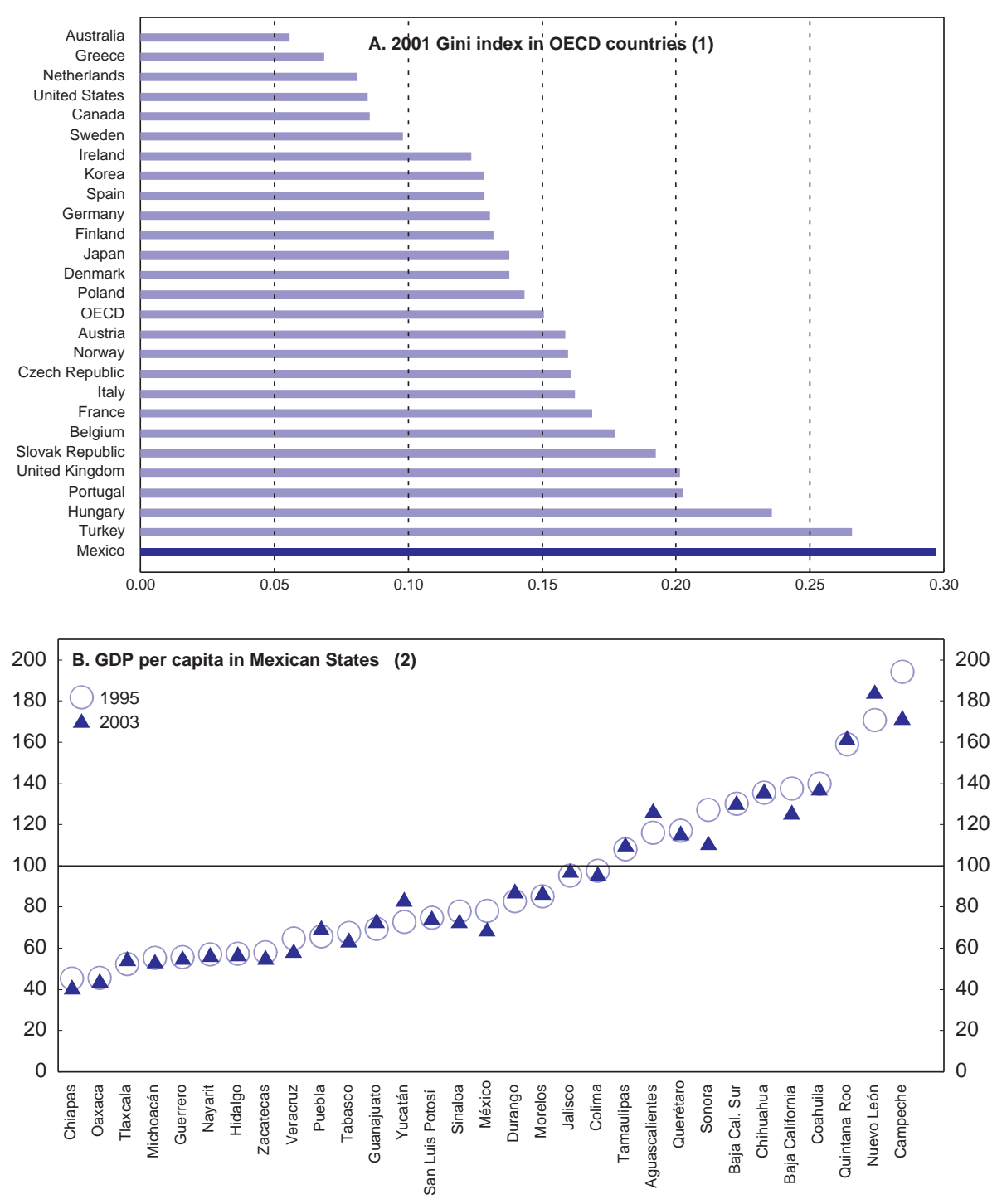

1. Gini coefficient with GDP per capita in territorial units weighted by population (209 regions for Mexico). 2000 data for Mexico, Norway and Turkey.

2. GDP per capita relative to average national GDP per capita $(=100)$. States are ranked in ascending order of the GDP per capita in 1995. The Federal District is not shown here, its per capita relative GDP was 245.0 in 1995 and 269.1 in 2003.

Source: OECD, OECD Regions at a Glance (2004); Inegi; Conapo.

\section{Spending assignment issues}

7. The devolution of responsibilities to the states since the early 1990s has concerned core spending programmes, namely education and health care (Box 1). ${ }^{5}$ At the municipal level, the last major devolution - water provision and treatment - dates back to the early 1980s. Overall, sub-national governments' share in general government outlays rose from $11 \%$ in 1990 to about one third in 2003, i.e. about the average of

5. In 2002, spending on health and education accounted for 21 and $37 \%$, respectively, of general government final consumption. 
the OECD area. While one of the main objectives of this decentralisation process was to bring decisions closer to citizens, it has had to be balanced against several others, most notably: redressing some of the wide regional disparities in public services; upgrading their quality which is, for many of them, low by OECD comparison; and minimising the risk of a sub-optimal provision of services whose benefits are shared across several jurisdictions. In practice, the federal government has retained most of the regulatory powers and finances core sub-national governments' spending programmes (in particular health care and education) through earmarked grants (aportaciones) although sub-national governments have complete discretion on how they spend the resources transferred to them through the revenue-sharing arrangement (participaciones) and their own taxes. This section assesses the benefits and limits of this decentralised approach for the delivery of public services, largely drawing on the experience in the education and health care sectors.

\section{Box 1. The sharing of responsibilities across levels of government for key public services}

The management of several core public services has been transferred to sub-national governments since the mid-1980s, a process which gained in importance in the late 1990s. However, allocation of expenditure functions to sub-national governments is more a delegation of federally-controlled budgetary functions than a substantial granting of autonomy in programme design.

Health care services. State Health Services are open to all Mexican citizens but the majority of users are those not covered by social security institutions (i.e. about half of the population, including those working in the informal sector and the unemployed). A first wave of decentralisation was carried out during the period 1984-88 but its coverage remained limited both in terms of states concerned (14) and of flexibility in day-to-day management. The decentralisation process resumed in the period 1996-98: all states and the Federal District of Mexico were given responsibility for managing health care services and acquired more flexibility in the use of federal government resources (in particular by suppressing the line-budgeting approach). The federal government has retained control, however, of most regulatory functions and establishes standards and quality controls. Negotiations on salaries and employment conditions have also continued to take place at the federal level, between the national unions and the federal Ministry of Health. Parallel to the states' health care services, the federal government finances the IMSS-Solidaridad programme which aims at providing health care services in the most deprived areas. In addition, the System for Social Protection in Health (SPSS) that came into effect in 2004 created a family insurance (Seguro Popular) to ensure that all individuals have access to health care insurance. Although implemented by the states, the cost is to fall largely on the federal budget.

Basic education. In 1992, the responsibility for operating the basic education system and of training teachers was transferred to the states. Federal school facilities and employees (about 700000 federal teachers) were put under state administration. The federal government has, however, retained almost exclusive control over plans and programmes of study, compulsory and optional subjects, choice of (free) text books, the length of the school year and the assessment of education outcomes. Annual wage adjustments for all teachers are negotiated first between the federal government and the national trade union and then at the state level. Municipalities are responsible for the maintenance of primary education infrastructure while the states are responsible for the building of new infrastructures.

Anti-poverty programmes. Responsibility is shared across levels of government, although the PROGRESA/Oportunidades programme managed by the federal government accounts for the lion's share. This programme aims at developing human capital of poor households through an integrated approach, giving direct cash payments to eligible families as incentives to increase use of education and health services and to promote food consumption. States and municipalities receive earmarked grants (FAIS) from the federal government - about $0.3 \%$ of GDP in 2004 - to fund social infrastructure in selected areas (including water drainage and sewerage, urbanization, electricity, basic health and education infrastructure, rural roads, housing improvement).

Water. Responsibility for water distribution, drainage and the sewerage system was transferred to municipalities in 1983 (together with public lighting, garbage collection, public markets, cemeteries, public parks and public safety). The federal government, however, contributes up to $45 \%$ to the financing of water infrastructure. 


\subsection{Although limited in scope, decentralisation has spurred innovations in management ...}

8. One key positive feature of the decentralisation process has been the introduction of promising managerial innovations in some states to better suit local needs. ${ }^{6}$ A few of them (including Chiapas and Jalisco) have introduced a modern budgetary and payment information system which simplifies the registration and control of financial operations, thus reducing the scope for corruption. Chiapas also created a system (gobierno express) to provide administrative services and ease tax compliance for individuals and companies, reducing the common practice of charging bribes for "queue-jumping". ${ }^{7}$ Some states have improved the selection of teachers which used to be largely controlled by trade unions by introducing a formal examination either to enter teacher training colleges (e.g. Sonora) or on completion (e.g. Chiapas). A new approach for improving public service delivery in remote areas is being developed; breaking from the traditional top-down approach, it is based on consultations and negotiations across levels of government and with the civil society (OECD, 2005a). Successful experiments in one state are also increasingly diffused to other states, helped by the regular meetings of federal and state spending ministries. ${ }^{8}$ As an example, the interesting experiment of providing education loans to needy families in the state of Sonora (Instituto de Crédito Educativo de Sonora) has been replicated in 5 states since 1999. Likewise, pilot programmes of health care family insurance system in some states in the early 1980s preceded the institutionalisation in 2004 of a popular insurance system (Seguro Popular), which now covers all states, in the context of the Social Protection in Health reform. This suggests that experimentation at the sub-national level has a role to play in designing public policy nationwide. ${ }^{9}$

9. Decentralisation has resulted in a segmentation of information. There is now a lack of data on the total amount of public spending on primary education. Similarly, in the health care sector not all states provide information on their own contribution to health care services, so that breaking down national public spending by main categories is difficult (Moreno Jaimes, 2001). This loss of information complicates the identification of national priorities and appropriate policy response to achieve them.

\subsection{Several factors have limited effective autonomy and accountability at a sub-national level}

10. All three levels of government have concurrent obligations for important services. As examples, the federal government finances university and hospital infrastructure, while the states are responsible for maintenance. Likewise, municipalities are responsible for maintaining school buildings while federal and state governments carry out the vast majority of capital investment. In the health care sector, the

6. Regulations on school buildings' architectural design provide an example of the rigidities impeding subnational governments from taking account of the local environmental characteristics before the decentralisation process. Up to 1996, a federal committee (CAPFCE) centralised almost all the responsibilities in the construction, equipment, rehabilitation and maintenance of school infrastructure. CAPFCE's buildings were the same throughout the country, colour included (Alvarez, 2002).

7. For instance, obtaining a car registration plaque now takes about 5 minutes in Chiapas while in some states citizens can wait several months.

8. In the health care sector, the National Health Council (Consejo Nacional de Salud) established in 1995 brings together health authorities from the federal and state governments four times a year in order to ensure co-ordination in the National Health System. It proposes concerted actions, has standardised evaluation procedures and developed technical co-operation between states. In the education sector, the federal government organises meetings with states' education ministries to share information on successful experiments.

9. In the United States, a similar experimentation process was carried out for the programme Temporary Assistance for Needy families (forthcoming OECD Economic Survey of the United States). See also Oates (1999) for a discussion on the potential for experimentation and innovation associated with decentralisation. 
IMSS-Oportunidades aimed at providing health services to inhabitants of deprived areas is financed by the federal government and partly overlaps with the states' health services. In this context, each level of government can blame the other for not doing its part, resulting in under-provision of some services and poor cost-efficiency of public spending programmes. A recent poll survey indeed suggests that a large majority of the population does not really know what the responsibilities of each government level are (Hernández Trillo and Torres Rojo, 2004). The accountability of sub-national government representatives is further diminished by the no re-election rule - the governors of the 31 States are elected for non-renewable 6-year terms and mayors of the 2450 or so municipalities are elected for 3- or 4- year non-renewable terms. This rule partly reflects a concern that checks and balances were too weak in the past to mitigate the powers of patronage provided by elected office. Still, the re-election ban greatly reduces incentives for elected officials to initiate beneficial programmes that have up-front costs and major long-term benefits. Examples at the municipal level include the updating of the land register so as to improve collection of the real estate tax or investment in water facilities.

11. Overly rigid public job status and pay conditions largely set in practice at the federal level limit sub-national governments' autonomy in human resource management and, hence, their ability to improve the cost-effectiveness of public services. Policies regarding human resources in the education and health care sector are in principle in the hands of the states and some states have developed innovative approaches. Their room for manoeuvre in these areas remains, however, limited by a federal labour contract that existed prior to decentralisation and which continues to set working conditions. ${ }^{10}$ Even though public employment at the state level now accounts for the lion's share of total public employment (Figure 3), annual wage adjustments are dominated by the negotiations carried out between national unions and the federal government and may thus fail to reflect the actual financial situation in some states and differences in living costs across jurisdictions. ${ }^{11}$ The life-long job contract also makes it difficult for subnational governments to sanction poor performers - a serious issue in the education and health care sectors plagued by a high rate of absenteeism. Exacerbating this, functional and geographical mobility of public employees is extremely limited, partly reflecting the lack of integration of pension systems across states and the large role of the trade unions in selecting and placing public employees. ${ }^{12}$ This has made it difficult to adjust to changing needs for public services, creating upward pressures on public employment. In practice, states have increasingly relied on temporary workers, in particular in the health care sector, with lower wages and limited social insurance coverage.

10. At the time of decentralisation, former federal employees had more favourable wage conditions than state employees with similar positions in both the education and health care sector. This has created pressures for an upward adjustment in state employee wages, putting some states under serious financial strain. On the other hand, state pension systems are often more generous than the pension system for federal government's employees, at least for teachers, auguring future tensions on the states' public finance.

11. For teachers, state sections of the trade union negotiate a second package of wage increases and benefits with each state after national negotiations.

12. In the health care sector, Paqueo and González (2003) noted that the formal rules and norms for health care professionals accompanying the decentralisation reform were established by the federal government and the central health labour union (without any input from the states). One of these agreements gives the labour union the right to nominate replacements and has led to the practice of nepotism. The labour union effectively decides on $50 \%$ of staff replacements. In the education sector, the trade union also has an important role in the selection and placement of teachers. 
Figure 3. Public sector employment in perspective
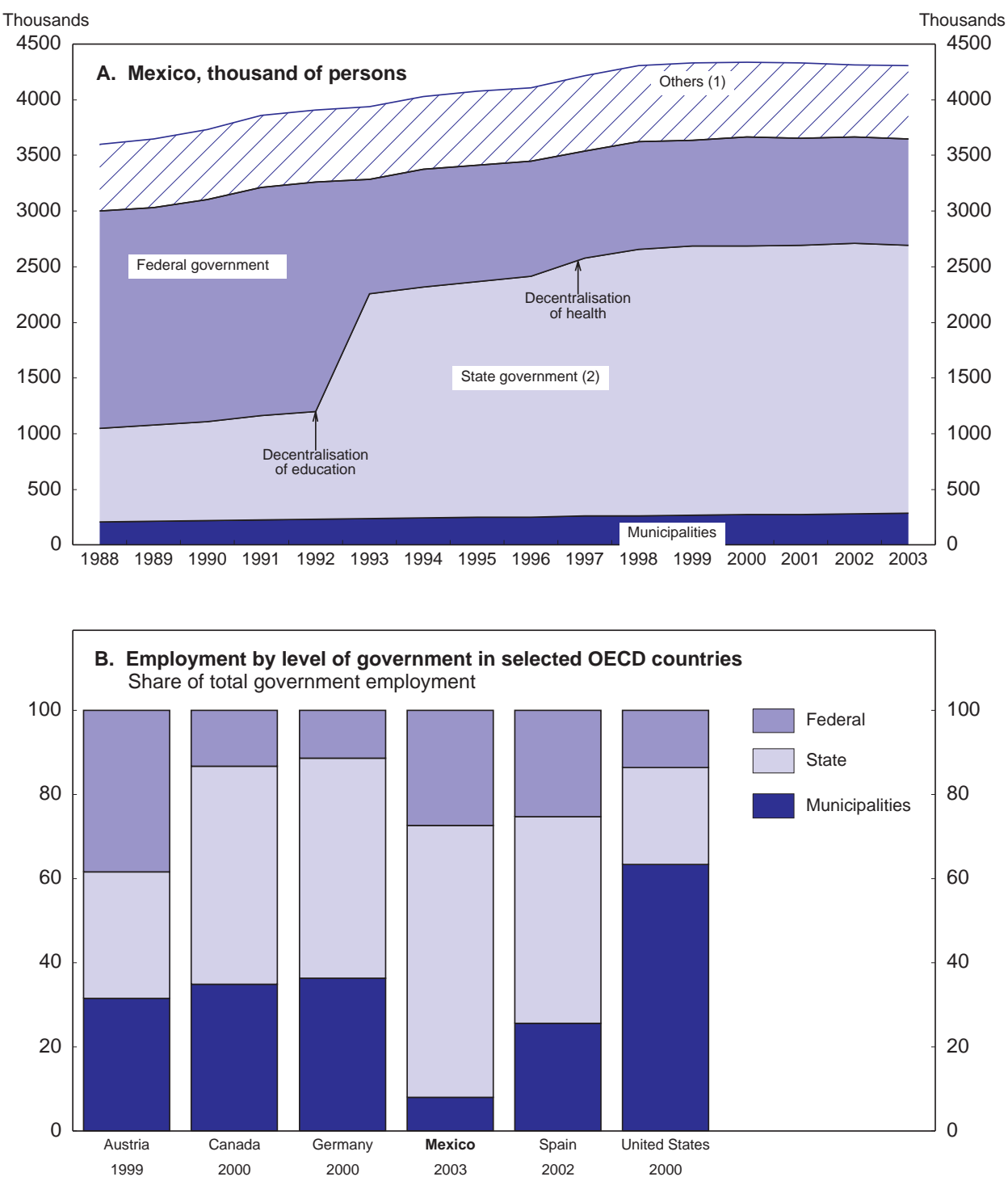

1. Includes social security system and public entities in the central government.

2. Includes the District Federal.

Source: INEGI, Sistema de Cuentas Nacionales de México, 1988-2002; OECD, Public Sector Pay and Employment database; Spain, National Institute of Statistics. 


\subsection{The design of earmarked grants perpetuates regional disparities, ...}

12. Spending responsibilities transferred to sub-national governments have largely been financed through earmarked grants, amounting to $4.5 \%$ of GDP in 2003. Allocated on a discretionary basis up to 1998, they are now largely governed by formulae. Such a use of formulae has improved transparency and helped to reduce moral hazard problems but has raised important equity considerations. The existence of regional spillovers in sub-national spending programmes would be a valid argument for relying to some extent on earmarked grants, so as to avoid sub-optimal spending at a local level. In the case of similar spillover effects across states, then states should receive the same level of earmarked grants per head. In Mexico, however, the amount of federal grants earmarked to health care and education received by each state largely reflects the costs the federal government incurred previously in delivering these services (Box 2). ${ }^{13}$ Thus, inequities in federal spending across states prior to the decentralisation - with richer states often being much better endowed than poorer states - have been largely perpetuated. In fact, the amount received both for health care per non-insured person and for education per pupil varies tremendously across states, with poorer states tending to receive less than richer ones (Figure 4). ${ }^{14}$ The distribution of the grant earmarked for "strengthening sub-national government finances" (PAFEF) displays a similar, though less pronounced, regressive bias. These inequities in federal grants received by sub-national governments are often reinforced by the revenue-sharing arrangement between the federal government and the states and by the system of sub-national taxes (see below). In contrast, the earmarked grant for social infrastructure (FAIS) displays a clear redistributive pattern.

13. A similar approach was adopted in Spain for the health care sector (Joumard and Giorno, 2005) although in that country, the inverse correlation between income level of the regions and the existing facilities installed was much less pronounced than in the case of Mexico.

14. In the health care sector, inequities in the distribution of grants across states are exacerbated by the fact that the richest states tend to have the highest levels of coverage by the social security system which benefits from a much higher implicit subsidy than the State Health Services per served person. 
Figure 4. Distribution of the main earmarked grants across sub-national governments
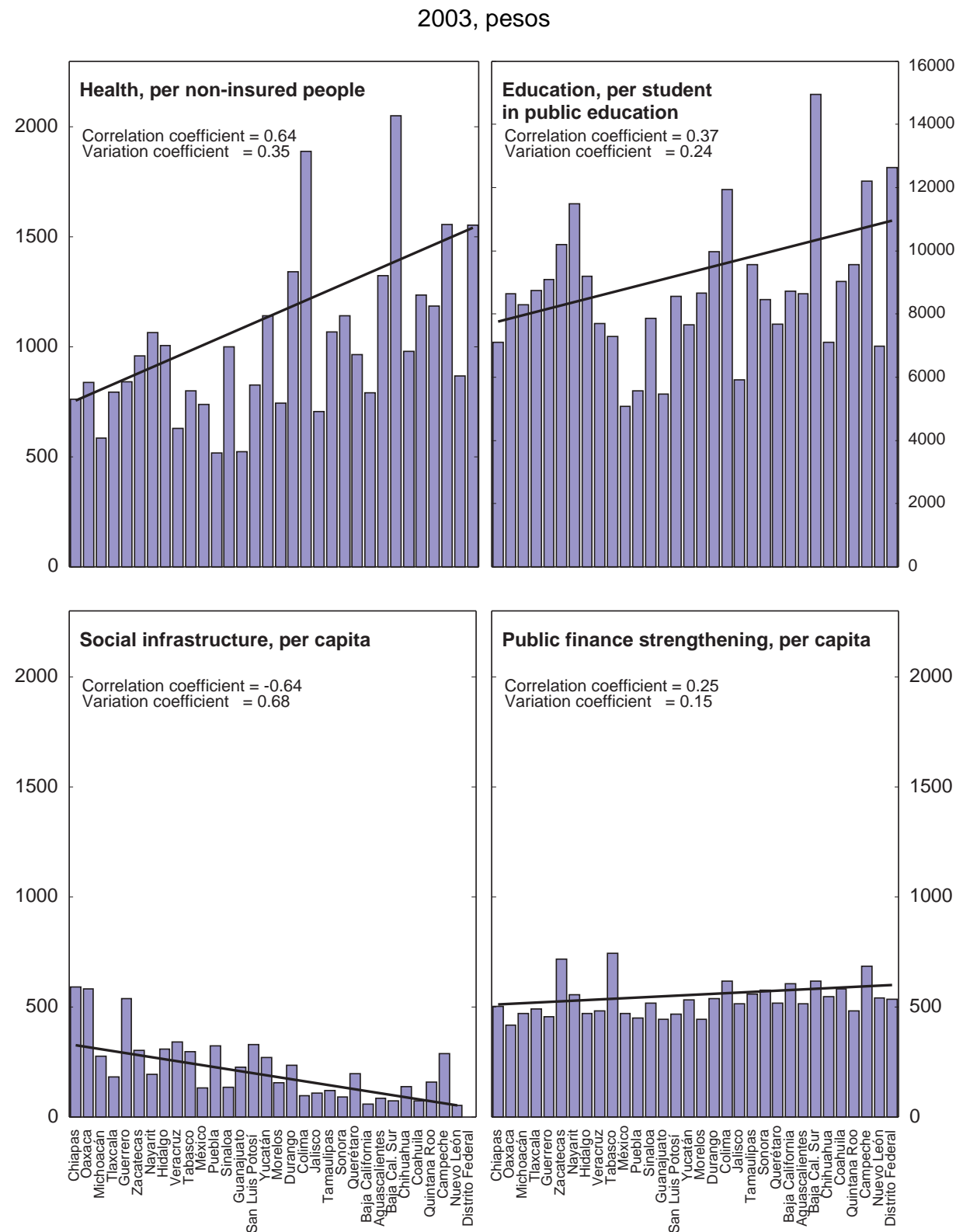

Note: States are ranked in ascending order of the GDP per capita in 2003. The solid line represents the regression line between the indicated grant and the GDP per capita. For health, Colima and Baja California Sur are excluded from the regression line and for education Baja California Sur is excluded.

Source: Ministry of Health, Información estratégica de gasto público en salud 1999-2003; Ministry of Education, Sistema Educativo de los Estados Unidos Mexicanos, principales cifras, ciclo escolar 2003-2004; Ministry of Economy, Cuenta de la Hacienda Pública Federal 2003; Conapo; Inegi. 


\section{Box 2. Main earmarked grants: criteria used to set the amount and to distribute them across sub-national governments}

The current federal earmarked grant system (aportaciones federales) was created with the reform of the Law on Fiscal Co-ordination in 1998. Under this law, the distribution of earmarked grants across sub-national governments is largely based on formulae, contrasting with the previous system characterised by a high degree of discretion. In principle, control on the use of these grants is carried out by the federal government and national Congress, whereas for block grants (participaciones), the state Congress exercises control. Overall, earmarked grants accounted to half of sub-national governments' financial resources in 2003 (i.e. 4.5\% of GDP). The main earmarked grants are targeted at basic education, health care, social infrastructure and actions to strengthen states' and municipalities' public accounts (Figure 5). ${ }^{1}$

Figure 5. Main earmarked grants to sub-national governments

As a percentage of total earmarked grants in 2004 (1)

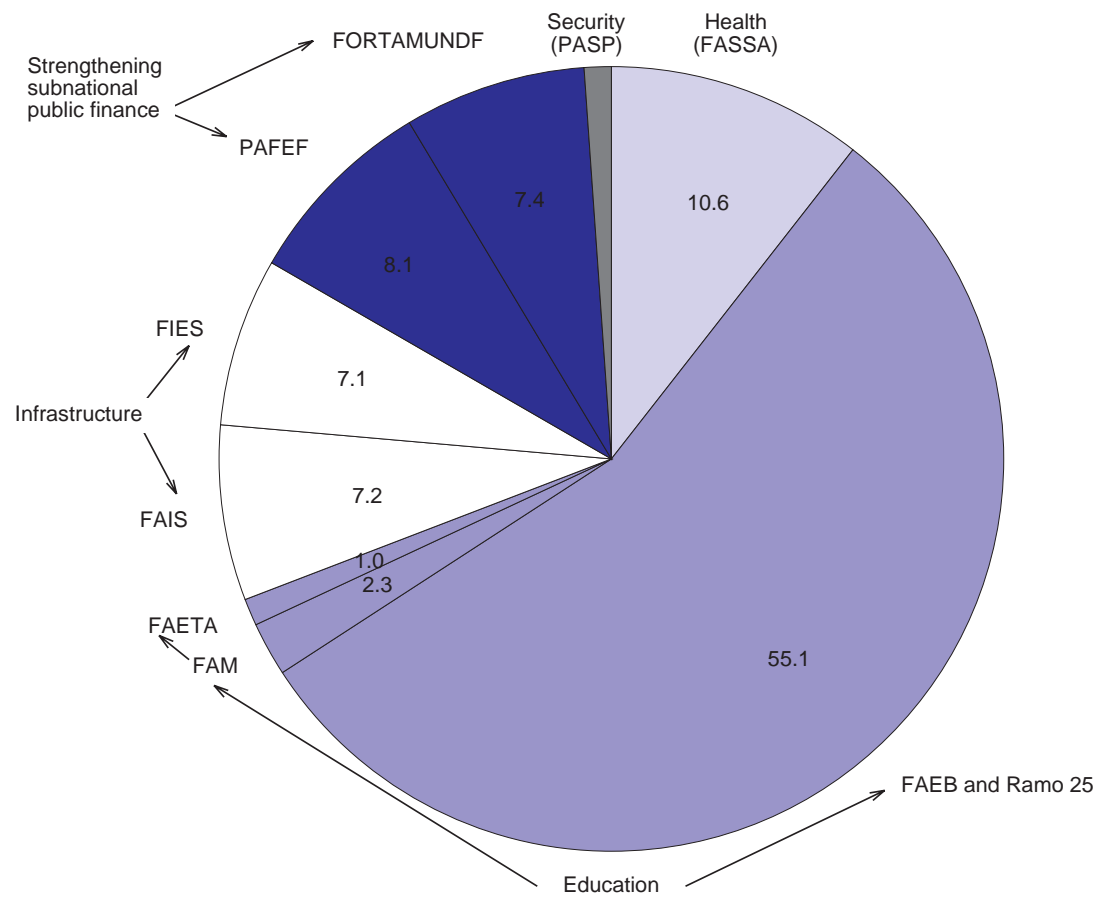

1. Provisional data.

Source: INAFED.

Education. The main earmarked grant is the basic education grant (Fondo de Aportaciones para la Educación Básica, $F A E B$ ). At the time of the decentralisation, the amount received by each state from the FAEB reflected mainly historical costs for the federal government when providing this service. Each year, the FAEB received by individual states is adjusted at the margin to reflect changes in the number of schools and teachers. For basic education, states also receive a federal grant earmarked to education infrastructure and to provide breakfast for those at school (under the Fondo de Aportaciones Múltiples, FAM). The overall amount of the FAM is set as $0.814 \%$ of the "sharable tax revenues" (the so-called RFP ${ }^{1}$ ) and its distribution across states is largely based on objective-needs criteria: number of registered pupils, number of school-age pupils not attending schools, increase in school-age children and the degree of marginality of the jurisdiction. The federal grant earmarked to technological and adult education (Fondo de Aportaciones para la Educación Tecnológica y de Adultos, FAETA) is, like the FAEB, largely allocated on the basis of actual spending (mainly existing facilities and human resources employed under such programmes). 


\section{Box 2. Main earmarked grants: criteria used to set the amount and to distribute them across sub-national governments (contd.)}

Health care. The main earmarked grant for health care is the FASSA (Fondo de Aportaciones para los Servicios de Salud). At the time of the decentralisation, the amount received by each state from the FASSA reflected mainly historical costs for the federal government when providing this service. Each year, the FASSA received by individual states is adjusted to reflect installed facilities and the number of health care professionals. A small fraction of the FASSA is further distributed to reflect objective needs (non-insured population). Overall, historical patterns of budget allocations at the time of decentralisation continue to play the dominant role (Moreno Jaimes, 2001).

Infrastructure. There are two main grants earmarked for investment in infrastructure by sub-national governments: the Social Infrastructure Fund (FAIS) and the Trust Fund for Infrastructure in the States (FIES). The FAIS is set at $2.5 \%$ of the "sharable tax revenues" (the so-called RFP"). The main objective of the FAIS is to improve infrastructure in most marginalised areas. Its distribution across states is based on several extreme poverty indicators measured through the income level and the access to basic public services of the population (such as the share of households without a connection to an electricity and/or water provision system). Each state has to redistribute to municipalities $88 \%$ of the federal grant, choosing between two formulae: one replicates the federal government formula; the other gives more weight to population (thus being less favourable to remote rural areas). These funds should be used on specific areas, including: drinking water, sewage, urban public works, electrification of rural areas and basic health and education infrastructure. In contrast with the FAIS, the FIES has no redistributive objective. It is set as a percentage of "excess oil revenues" (i.e. any positive deviation from the Budget projections). It is distributed across states in line with the revenue-sharing system, i.e. richer states tend to receive more (see below).

"Strengthening sub-national governments' public finance" (PAFEF and FORTAMUN). Initially, the Fund to strengthen states' finance (PAFEF) created by the Congress in 2000 was devoted mainly to education infrastructure in those states where education spending was below national average. In 2001, the use of the PAFEF was extended to any infrastructure and to address problems with their pension system. In 2002, debt relief was recognised as a new spending area. The overall amount of the PAFEF is set each year in the budget process and there is no clear allocation criteria across states. In 2005, there were 8 spending areas: infrastructure, pension systems, financial improvement (i.e. any measures to strengthen public finances of states such as debt reduction, contingent liabilities or to face specific spending pressures), land register modernisation, improvement in local tax collection systems, development of mechanisms to improve the tax base, science and technology, and civil protection. The Fund to strengthen municipal finance (FORTAMUN) was introduced in 1998. It is set at $2.56 \%$ of the RFP and distributed across municipalities and areas (demarcaciones) in the Federal District on a per capita basis. Municipalities can use this money to pay back their debt and to strengthen public security programmes.

1. Earmarked grants are channelled through two main appropriation lines. The so-called Ramo 33 includes the grants earmarked to health, education and social infrastructure. The fund to strengthen states' finance (PAFEF) and the Trust Fund for Infrastructure in the States (FIES) are included in the so-called Ramo 39.

2. Sharable federal revenues (RFP) consist of all federal government taxes and oil-related revenues, except for the additional and extraordinary fees from extraction of petroleum, as well as the federal tax on new motor vehicles and the tax on usage of cars which are directly appropriated by the states, and a percentage of excise taxes on tobacco and alcohol. The RFP amounted to 13\% of GDP and 56\% of total public sector revenues in 2004.

13. Recent efforts to redress the regressive bias in earmarked grants are commendable but their cost effectiveness could be improved. The 2003 reform establishing the System for Social Protection in Health (SPSS) has set a mechanism that should rectify the interstate inequalities by channelling new resources to poorest states. The federal fiscal costs will, however, be high (around two-thirds of a percentage point of GDP over the period to 2010). To deliver the expected outcomes - improving access to health care for the non-insured - the recent OECD Review on health care in Mexico (OECD, 2005b) identified the need for several reforms. In particular, administrative and management capacity of the states should be improved. States should be able to reform remuneration systems for both health care professionals and institutions so as to provide encouragement for increased and better quality care. In the education sector, adjusting federal grants to improve equity in per capita transfers across states would be even more costly for the budget - between $0.3 \%$ of GDP (if the objective were to bring those less-well-treated states to the current average) 
and $2.3 \%$ of GDP (if the objective were to give to all the best treatment - an approach followed in the health care sector to implement the Seguro Popular to ensure that all individuals have access to health care insurance). It also needs to be recognised that the costs of providing education services in some of the poorer states are likely to be much higher than in the richer states because of topographic and socioeconomic conditions (including the number of indigenous languages).

\section{$3.4 \quad \ldots$ and earmarked grants create adverse incentives for a cost-effective delivery of public services}

14. The formulation and implementation of earmarked grants raise several issues:

- Controls on their use exist practically only at the local level. This has helped to keep administrative costs lower than in some other countries, ${ }^{15}$ but there is no mechanism to ensure that earmarked grants respond to national priorities - the main justification for using earmarked grants in the first place. In particular, positive incentives or sanctions mechanisms are absent and information not well-developed. ${ }^{16}$

- The formulae used for setting the amount of the grants earmarked to education and health care (FAEB and FASSA) and for distributing them across sub-national governments are not based on objective criteria, but rather on actual supply and costs. This creates incentives to maintain obsolete infrastructures and keep excess capacity in the health sector. In the education sector, the grant formula creates incentives to increase the number of teachers, at the expense of other education inputs (such as classroom materials or the training of teachers). Furthermore, it discriminates against those states which had developed their own education system before the decentralisation process since associated costs have not been recognised by the federal government. ${ }^{17}$ It also largely neglects demographic developments, in particular migration flows across states.

- The criteria used for the Social Infrastructure Fund (FAIS) can trigger strategic games since any improvement in the availability of core public services would result in a cut in the grant for the next period. Partial evidence suggests that municipalities which qualify for the FAIS, because a high proportion of households does not have access to water provision facilities, tend to use the FAIS money for other purposes so as to continue receiving the grant.

- The newly created grant earmarked to strengthen states' financial positions (PAFEF) is not governed by any formula, either in setting its overall amount or in distributing it across states. This could create serious moral hazard problems, with states making no effort to keep their public finances in order so as to receive more generous grants.

15. In Austria for instance, administrative costs associated with earmarked grants were found to be substantial, arising from application procedures involving potential beneficiaries, establishing evidence that funds were used as approved, and related activities. Such costs are particularly high for small municipalities where they were estimated to reach between 10 and $20 \%$ of the grant (OECD, 2005c). Managing earmarked grants has generated high administrative costs in a number of other OECD countries, including Germany, Switzerland and the United Kingdom.

16. As an illustration, Moreno Jaimes (2001) notes that although the National Health Council is responsible for assessing state health policies and outcomes, there is no clear sanction/incentive mechanisms should a state deviate from standards set by the federal government.

17. In Estado de México, Nuevo León and Baja California, about half of the students were registered in schools managed by the states before the decentralisation took place (Merino, 2001). 


\section{Issues in funding arrangements for sub-national governments}

15. With large spending responsibilities at the sub-national government level, the main challenges on the funding side are: first, to provide sub-national governments with sufficient revenue-raising autonomy to make them accountable to local citizens; and second, to ensure that all have enough financial resources to provide a certain level of core public services. Yet Mexico stands out as having a highly centralised tax system, resulting in a very large fiscal gap at the sub-national level which is filled by intergovernmental transfers. Another specificity is the revenue-sharing system (participaciones) whose main purpose is not to redistribute fiscal capacity from rich to poor jurisdictions - it was originally designed to compensate sub-national governments for having relinquished their taxing powers to the federal government in the early $1980 \mathrm{~s}$.

\subsection{Tax revenues account for a marginal share of sub-national governments' financial resources}

\subsubsection{Sub-national governments have few taxing powers and hardly use those they have...}

16. Sub-national governments' tax autonomy is extremely limited and recent reforms ceding new taxing powers to the states have met with little success so far. Sub-national governments' own taxes (i.e. those over which they have some discretion in setting either the base or the rates) accounted for only $4 \%$ of Mexico's total tax revenues (including social security contributions), and less than 5 and 10\%, respectively, of the states' and municipalities' financial resources in 2002 (Figure 6). A study on subnational government taxing powers in 1995 revealed that Mexico ranked last out of 20 OECD countries surveyed (Table 1). Since then, taxing powers have not changed much while core spending responsibilities have been decentralised, increasing further the mismatch between spending and revenue-raising powers. This low tax autonomy also contrasts with the extensive taxing powers sub-national governments had before the 1980 implementation of the National System of Fiscal Co-ordination (Box 3). 
ECO/WKP(2005)40

Figure 6. Sub-national financial resources

At 2003 prices, million of pesos

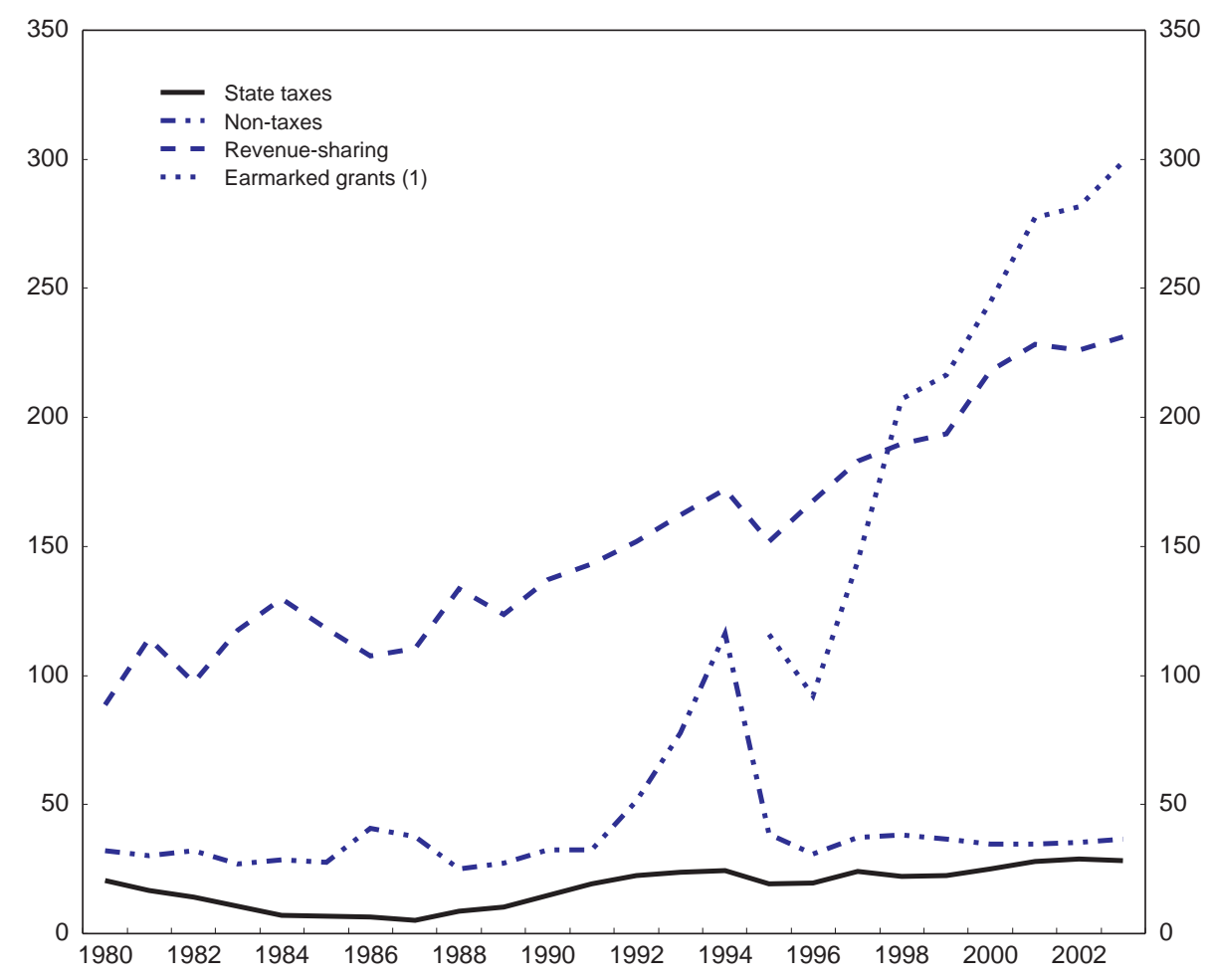

1. Before 1995 data are not available.

Source: CEFP, Indicadores de Finanzas Públicas por Entidad Federativa, 1980-2002; INEGI, Finanzas Públicas Estatales y Municipales de México 1999-2002. 
ECO/WKP(2005)40

Table 1. Sub-national government taxing powers in selected OECD countries ${ }^{1}$

1995

\begin{tabular}{|c|c|c|c|c|}
\hline & \multicolumn{2}{|c|}{ Sub-national government taxes relative to: } & \multirow{2}{*}{$\begin{array}{c}\text { Discretion to set } \\
\text { Taxes }^{2}\end{array}$} & \multirow{2}{*}{$\begin{array}{l}\text { Summary indicator } \\
\text { of taxing powers }{ }^{3}\end{array}$} \\
\hline & Total taxes & GDP & & \\
\hline Sweden & 32.6 & 15.5 & 100.0 & 15.5 \\
\hline Denmark & 31.3 & 15.5 & 95.1 & 14.7 \\
\hline Switzerland & 35.8 & 11.9 & 92.4 & 11.0 \\
\hline Finland & 21.8 & 9.8 & 89.0 & 8.7 \\
\hline Belgium & 27.9 & 12.4 & 57.9 & 7.2 \\
\hline Iceland & 20.4 & 6.4 & 100.0 & 6.4 \\
\hline Japan & 24.2 & 6.8 & 90.3 & 6.1 \\
\hline Spain & 13.3 & 4.4 & 66.6 & 2.9 \\
\hline New Zealand & 5.3 & 2.0 & 98.0 & 2.0 \\
\hline Germany & 29.0 & 11.1 & 12.8 & 1.4 \\
\hline Poland & 7.5 & 3.0 & 46.0 & 1.4 \\
\hline United Kingdom & 3.9 & 1.4 & 100.0 & 1.4 \\
\hline Netherlands & 2.7 & 1.1 & 100.0 & 1.1 \\
\hline Austria & 20.9 & 8.7 & 9.5 & 0.8 \\
\hline Portugal & 5.6 & 1.8 & 31.5 & 0.6 \\
\hline Czech Republic & 12.9 & 5.2 & 10.0 & 0.5 \\
\hline Hungary & 2.6 & 1.1 & 30.0 & 0.3 \\
\hline Norway & 19.7 & 7.9 & 3.3 & 0.3 \\
\hline Mexico & 3.3 & 0.6 & 11.2 & 0.1 \\
\hline
\end{tabular}

1. The countries are ranked in descending order according to the value of the summary indicator of taxing powers.

2 The figures show the percentage of their total taxes for which sub-national governments hold discretion over the tax rate, the tax base or both the tax rate and the tax base. A value of 100 designates full discretion.

3. The summary indicator is the product of the ratio of sub-national government taxes to GDP and the degree of discretion to set taxes. Thus, it measures sub-national government taxes with full discretion as a percentage of GDP.

Source: OECD, Taxing Powers of State and Local government, 1999 and Revenue Statistics 1965-2001, 2002. 
ECO/WKP(2005)40

\title{
Box 3. The sharing of taxing powers and revenues across government levels since the $1980 \mathrm{~s}$
}

\author{
High sub-national government tax autonomy resulting in a distortive tax system until the late 1970 s
}

Until 1980, states had wide taxing powers. This resulted in a very complex tax system (up to 430 different taxes on consumption and productive activities existed), tax cascading, an inefficient allocation of resources and even state tax wars. In addition, the lack of co-operation across government levels made it difficult to administer the tax system.

\section{Tax centralisation in $1980 \ldots$}

The National System of Fiscal Co-ordination (NFSC) was implemented in 1980 with the objective of improving the efficiency of the tax system. The NFSC established two contracts between the states and the federal government. Through the Adhesion Contract, states agreed to restrain their tax autonomy and to receive in return (unconditional) revenue-sharing transfers from the federal government (the so-called participaciones). The NFSC regulates tax responsibilities across government levels, with the objective of preventing double or even triple taxation of a single source of income. In particular, corporate income, excise and the newly created value-added taxes became exclusively federal. The Administrative Co-operation Contract provided guidelines for improving tax collection of federal taxes: states have the rights to enforce and collect some federal taxes and keep most of the extra-revenue from these activities.

... combined with a revenue-sharing arrangement

While centralising a large number of taxes, the NFSC also defined how revenues of the main federal taxes would be shared, both between the federal and sub-national governments and across states:

- Originally set at $18.1 \%$, the states' share in "sharable federal revenues" (the so-called RFP) through the General Participation Fund (participaciones) was increased in 1996 and stood at 20\% in 2005. Efforts to improve tax collection have further contributed to the growth in revenue-sharing transfers received by the states - the RFP rose in real terms on average by $3.5 \%$ each year over the period 1990-2002.

- The distribution of revenue-sharing transfers across states was originally designed to compensate the states for relinquishing their taxing powers. Thus, richer and oil-producing states have received more than poorer states. The distribution formula was later adjusted to better reflect needs (states' population became an important criteria) and, in 1994, to reward states for improving the collection of some federal taxes. In 2005, $45.17 \%$ of the participaciones were distributed across states on an equal per capita basis; $45.17 \%$ on the basis of actual efforts to raise revenues from three federal taxes (taxes on specific goods and services IEPS, federal tax on the use of cars Tenencia and federal tax on the acquisition of a new car ISAM) and the remaining $9.66 \%$ as the inverse of the previous two criteria. The last component gives a rather favourable treatment to states with few inhabitants.

States are required to allocate at least $20 \%$ of the revenue-sharing grants they receive from the federal government to the municipalities, though there is no uniform and clear distribution formula across states. States use one, or a combination of, criteria: $84 \%$ of the states use population data; $52 \%$ revenues from the property tax; $45 \%$ an indicator for actual tax effort; 42\%, water rights (Ibarra Salazar and Varella Mollick, 2004). 


\subsubsection{Raising sub-national governments' own taxes has met serious constraints}

17. Payroll taxes account for the bulk of the states' own tax revenues, a unique feature among OECD countries (Table 2). ${ }^{18}$ Their main advantage is low administrative costs. Still, they have serious disadvantages:

- They are collected at the place of employment, as opposed to the place of residence, while core spending of the states benefits households (e.g. education and health care). Thus, when commuting between states is frequent, e.g. in the Mexico City metropolitan area which spans two states (Estado de México and the Federal District), revenues may flow to the "wrong" state.

- The sharing of tax bases when a company operates in several jurisdictions can create disputes between states or facilitate tax evasion since cross-checking of information between states is not well-developed. Duplication of procedures resulting from the absence of a common tax base is also wasteful for both taxpayers and administrations.

- The payroll tax adds to the cost of hiring workers in the formal sector.

- A payroll tax may discourage the innovation process by imposing a heavy burden on newlycreated companies with little or no profits. ${ }^{19}$

18. States' payroll taxes are deductible from the federal government's corporate tax base. This reduces competition pressures across states and the distortionary effect of any given level of payroll tax. On the other hand, deductibility fails to promote accountability at the state level and gives incentives to set payroll taxes too high: an increase in state taxes would ultimately partly be paid for by the federal government.

18. Only four OECD countries have a payroll tax at the sub-national level (Australia, Austria, Canada and Mexico). Only in Australia does the payroll tax account for a significant share of the states' tax revenues but, at 28\% in 2002, it remains much less important than in Mexico. In a number of other OECD countries (including France, Germany, Hungary, Italy, Japan and Spain), sub-national governments rely on business taxes based on the value of the company's inputs, value added or assets (or a combination of these). Such taxes have, however, raised a number of concerns and some have been reduced recently (Joumard and Yokoyama, 2005).

19. The incidence of payroll taxes may be partly shifted onto wages and/or prices, thus mitigating the third and fourth disadvantages of payroll taxes identified here. However, the large informal economy in Mexico likely limits the scope for tax-shifting. 
Table 2. Main own taxes of the states ${ }^{1}$

\begin{tabular}{|c|c|c|c|c|}
\hline & Base & Legal or actual rates & $\begin{array}{l}\text { Number of } \\
\text { states } \\
\text { implementing } \\
\text { the tax in } 2005\end{array}$ & $\begin{array}{l}\text { Revenues in } 2003 \\
\text { (as a share of } \\
\text { states' own tax } \\
\text { revenues) }\end{array}$ \\
\hline Payroll tax & $\begin{array}{l}\text { Labour } \\
\text { compensation (in } \\
\text { nature and cash). }{ }^{2}\end{array}$ & $\begin{array}{c}\text { States have full discretion to set } \\
\text { rates. Actual rates varies within a } \\
1 \text { to } 2.5 \% \text { range }\end{array}$ & 30 & $57.1 \%$ \\
\hline $\begin{array}{l}\text { Tax on transfers of } \\
\text { immovable } \\
\text { properties }\end{array}$ & Sales price & $\begin{array}{l}\text { States have full discretion to set } \\
\text { rates. }\end{array}$ & $\begin{array}{l}\text { Only the } \\
\text { Federal District }\end{array}$ & $6.8 \%$ \\
\hline $\begin{array}{l}\text { Tax on transfers of } \\
\text { cars and other } \\
\text { movable properties }\end{array}$ & Sales price & $\begin{array}{l}\text { States have full discretion to set } \\
\text { rates. }\end{array}$ & 29 & $2.9 \%$ \\
\hline $\begin{array}{c}\text { Tax on motor } \\
\text { vehicles older than } \\
10 \text { years }\end{array}$ & $\begin{array}{l}\text { Vehicles for personal } \\
\text { use above } 10 \text { years- } \\
\text { old }\end{array}$ & $\begin{array}{l}\text { States have full discretion to set } \\
\text { rates. }\end{array}$ & 15 & $2.3 \%$ \\
\hline $\begin{array}{l}\text { Tax on hotel } \\
\text { accommodation }\end{array}$ & $\begin{array}{l}\text { Price of the hotel } \\
\text { accommodation }\end{array}$ & $\begin{array}{l}\text { States have full discretion to set } \\
\text { rates. }\end{array}$ & 30 & $2.1 \%$ \\
\hline Tax on gambling & $\begin{array}{l}\text { Income received by } \\
\text { those organising } \\
\text { gambling }\end{array}$ & $\begin{array}{l}6 \% \text {. If states set rate above } 6 \% \\
\text { the federal government would } \\
\text { raise its own rate to } 21 \%\end{array}$ & 30 & $1.1 \%$ \\
\hline Tax on public shows & $\begin{array}{l}\text { Income received by } \\
\text { those organising } \\
\text { shows }\end{array}$ & $\begin{array}{l}\text { States have full discretion to set } \\
\text { rates }\end{array}$ & 11 & $0.4 \%$ \\
\hline $\begin{array}{c}\text { Surcharge on the } \\
\text { federal personal } \\
\text { income tax (created } \\
\text { by the } 2005 \text { budget } \\
\text { law) }\end{array}$ & $\begin{array}{l}\text { The base is set by } \\
\text { the federal } \\
\text { government }\end{array}$ & $\begin{array}{l}\text { Range set by the federal } \\
\text { government: } 2 \text { to } 5 \%\end{array}$ & 2 & Not applicable \\
\hline
\end{tabular}

1. This table only includes those taxes for which states have some powers to set either the tax base or rates.

2. Several states apply multiple rates according to the nature of economic activities and/or the number of employees.

3. The tax is imposed at a municipal level in 31 states.

Source: INEGI, Finanzas públicas estatales y municipales de México, 2000-2003. SHCP, Unidad de Coordinación con Entidades

Federativas. Diagnóstico Integral de la Situación Actual de las Haciendas Públicas Estatales y Municipales, 2005. 
19. The real estate tax, which has many attractive features as a sub-national tax, is the main municipal tax. Although it accounted for $60 \%$ of municipalities' own tax revenues in 2002, proceeds - at a quarter of a percentage point of GDP - are much lower than in most other OECD countries (Figure 7). The real estate tax has been plagued by ill-defined property rights. ${ }^{20}$ Transforming the real estate tax into a tax on land users, instead of owners, could ease this. It would, however, raise serious equity concerns since those using lands without well-defined property rights are often relatively poor peasants. The outdated land register (catastro) has been another limitation. Contrasting with the practice in several other OECD countries (including Belgium, France, Japan and Spain), the register is managed by local governments and, in a few cases, by the states. Updating it, entails high political costs in the short term, while the benefits are likely to accrue in the longer run and the short mandate for mayors, combined with the no-re-election rule, makes it politically unattractive. In addition, many small municipalities may lack staff with the necessary administrative skills to properly assess and collect the real estate tax. Finally, although the full revenues from the real estate tax have been assigned to municipalities since the 1986 constitutional reform, tax rates still have to be approved by the state's legislature.

Figure 7. Recurrent taxes on immovable property in OECD countries Revenues as a percentage of GDP, 2002

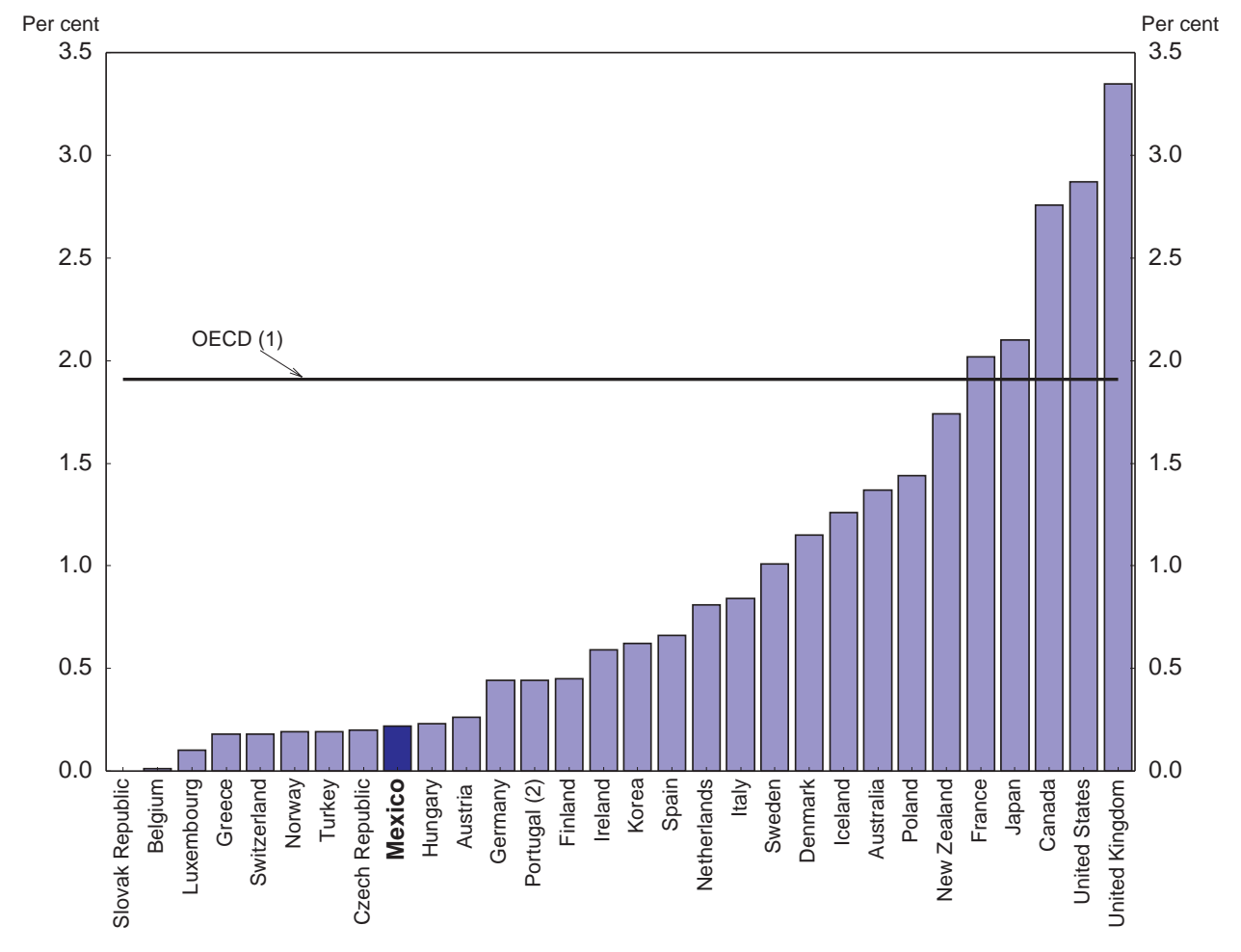

1. Weighted average using 2000 GDP and purchasing power parities.

2. 2001 data.

Source: OECD Revenue Statistics, 1965-2003.

20. A considerable space of land is currently without well-defined land titles. In 2003, $63 \%$ of the farm land corresponded to ejido. An ejido is a community based on land tenure that originated from the breakdown of large holdings of land at the end of the revolutionary period. Although modifications to the Constitution were carried out in 1992 to allow converting ejidos into private property, there exists a complicated legal process that has to be fulfilled by petitioners and the transition to private property has been much slower than anticipated. A programme to improve the land register with the latest geographical tools was introduced recently. 
20. Since the mid-1990s, the federal government has relinquished some of its tax bases to the states and allowed them to introduce new taxes (Box 4). These initiatives have had only limited success. None of the states implemented the options offered to them in 2002 of introducing a final sales tax, over and above the federal VAT, although the revenues would have been high. The transfer of tax auditing and collection functions to the states for key federal taxes, coupled with financial incentives (the states keeping most of the revenues from these activities while their individual share in federal revenues - participaciones increases with their actual tax collection efforts), has had more success. In particular, some of the poorer states (including Chiapas, Guerrero and Michoacán) have been successful in their efforts to improve tax collection, thus experiencing an increase in their share of the revenue pool. Others, however, have clearly lagged behind. Estimates from the federal government on the potential marginal revenues from increasing tax audits at the state level suggest that, overall, more could be achieved and that incentives to improve tax collection faced by sub-national governments are still insufficient. ${ }^{21}$

\section{Box 4. Main recent tax reforms to increase states' taxing powers since the mid-1990s}

1996

- $\quad$ States were authorised to levy a tax on hospital services and on ownership or use of old motor vehicles.

1997

- The federal tax rate on gambling was cut from 21 to $15 \%$ and states were allowed to impose a $6 \%$ rate on the same base.

- Under an administrative co-operation agreement, the states were authorised to administer a number of federal taxes (income tax, assets tax, excise tax for small taxpayers and VAT). This is an incentive for improving their collection capability insofar as they may keep any additional revenues resulting from the tax audits they conduct.

- $\quad$ States were made responsible for collecting the tax on new cars and the one of the use of cars. Proceeds from these taxes are now retained entirely by the states although they have no powers to set either rates or the base.

2002

- States were allowed to levy a $5 \%$ surcharge on the income of individuals with entrepreneurial activities under the regime for small taxpayers. This option was not used and was removed by Congress in 2003.

- $\quad$ States were allowed to introduce a new sales tax at a maximum rate of $3 \%$ on top of the federal VAT. This option was not used and was removed by Congress in 2003.

2003

- Through administrative co-operation agreements, the federal government transferred to states: i) revenue from the federal income tax on individuals with entrepreneurial activities under the regime for small taxpayers (i.e. income less than 2 million peso per year); ii) the equivalent of $5 \%$ of the revenue from the federal income tax on profits of individuals with entrepreneurial activities under the regime for intermediate taxpayers (i.e. income less than 4 million peso per year); and, iii) the equivalent of $5 \%$ of the tax on the capital gains from real estate transactions. Individuals can compensate any of these payments to states against their federal income tax.

2005

- The federal government continued to reduce its top rate from $33 \%$ in 2004 to $30 \%$ for personal income tax (a further cut to $28 \%$ in 2007 has been announced). At the same time, states were allowed to impose a 2 to $5 \%$ rate on the same base. By April 2005, two states (Chihuahua and Guanajuato) implemented the option while the Michoacán and Sonora Congresses were considering doing so.

21. From 2005, the federal government can take back the tax auditing responsibility from the states in the case of evidence of loose auditing at the state level. 
21. Recent adjustment in the grant system and political factors have jeopardised past initiatives to increase sub-national governments' tax revenues. With the emergence of a multiparty House of Representatives, the Congress has been very active in pushing for increased transfers to sub-national governments, and Federal government grants to sub-national governments have increased steadily since the early 1990s, softening budget constraints. The creation of the grant to strengthen states' public finance (PAFEF) by the Congress in 2000 is the most patent example. In this context, sub-national governments have been reluctant to pay the political cost of raising more taxes on their own citizens. At the municipal level, several empirical works also suggest that the generosity of the grant system, and in particular the introduction of grants earmarked for investment in 1998, has led municipalities to reduce their tax efforts. ${ }^{22}$ The lack of human, technical and administrative capacities to implement properly new tax prerogatives could also be a contributing factor.

\subsection{Revenue-sharing arrangement: a limited equalisation content}

22. Originally conceived to compensate sub-national governments for relinquishing their taxing powers, the revenue-sharing arrangement does not achieve much equalisation across jurisdictions. The National System of Fiscal Co-ordination (NSFC) stipulated in 1980 that no state should get less revenue under the tax centralisation option than they were collecting before joining the revenue-sharing scheme. Thus, until the early 1990s, richer states received up to 7 times more participaciones - the main revenuesharing arrangement, amounting to 3.4\% of GDP in 2003 - than poorer states. This contrasts with the approach followed in many other OECD countries (including Canada, Germany, Japan, the Nordic countries and Spain) where revenue-sharing arrangements, or more generally block grants, are the main tool to achieve some equalisation of fiscal capacities. The redistribution potential of the revenue-sharing arrangement has been improved since the early 1990s, reflecting various adjustments in the formula (see Box 3 above). Yet, per capita transfers received by rich and oil-producing states are still much higher than those received by poorer states (Figure 8). This allocation across states is further replicated for some of the grants earmarked for infrastructure (e.g. the FIES). The prospects for incorporating into the revenuesharing arrangement greater redistribution towards states with below-average potential tax revenues per capita are, however, limited since the NSFC gives the states the possibility to opt out of the system.

22. See Sour (2004) and Moreno (2003). The earmarked grants introduced in 1998 are the Fund to support municipal social infrastructure (FAISM) and the Fund for strengthening municipalities and the federal district (FAFM). 
Figure 8. Per capita transfers received by states through the revenue-sharing scheme1

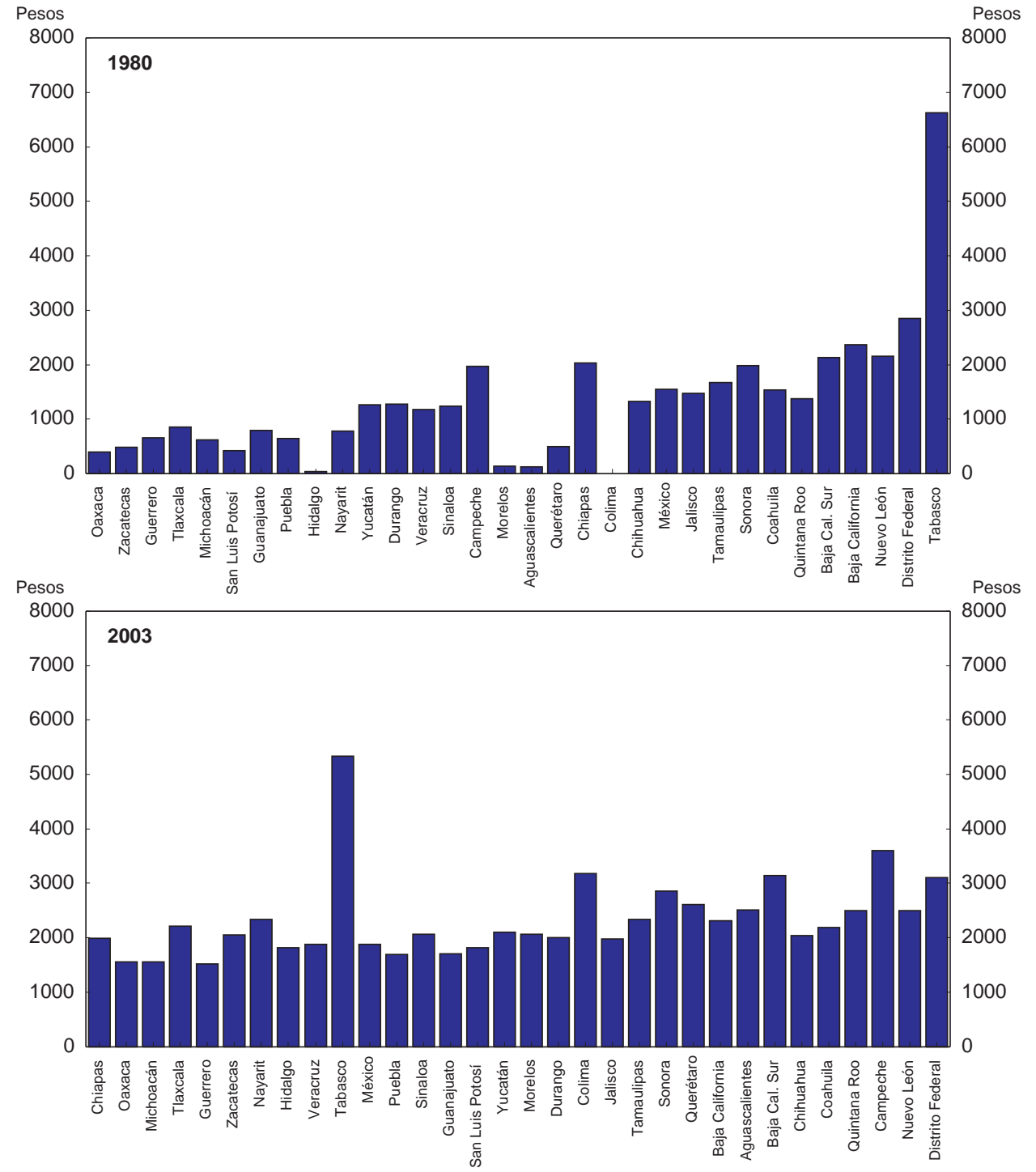

Note: States are ranked in ascending order of the GDP per capita in 1980 and 2003.

1. The main transfers under the revenue-sharing schemes shown here include: the so-called General Participation Fund, the Contingency Reserve, the Municipal Development Fund, revenues from the special tax on products and services (IEPS), revenues from the taxes on new and old cars (ISAN and Tenencia).

Source: Data for revenue sharing are from CEFP/024/2003, Indicadores de Finanzas Públicas por Entitad Federativa 1980-2002; 2003 data from SHCP. Population 1980, 2000 Inegi, México en el siglo XX; 2003 data from Conapo; GDP per states from Inegi, BIE.

\subsection{Options for changing the revenue mix of the states}

23. Reducing states' dependence on federal government transfers and increasing their revenueraising powers would likely enhance accountability and harden the budget constraint. States should be attributed at least one main tax, possibly substituting for the existing payroll tax which has raised various concerns. However, there are few taxing powers which can be exercised at the sub-national level without raising equity and/or efficiency concerns (Joumard and Kongsrud, 2003). Regarding efficiency, devolving 
taxing powers to sub-national governments risks entailing higher collection and compliance costs and creating distortions in inter-jurisdiction trade and/or the capital and labour markets. The choice of the tax base is of importance in minimising the efficiency costs of tax decentralisation. As regards equity, the distribution of tax bases across states is very uneven in Mexico but, again, some are likely to be more evenly distributed than others (in several countries per capita revenues from consumption taxes tend to be more evenly distributed than those from income taxes for instance).

24. Two main revenue-neutral options have been considered by national authorities so far in Mexico: giving states the opportunity to introduce a sales tax, over and above the federal VAT, or a surcharge on the federal income tax on individuals (impuesto cedular). In both cases states would be given the power to set rates within a range set by the federal government. For 2005, the federal government proposed both options but Congress approved only the personal income tax surcharge. This option has the merit of not significantly raising compliance and collection costs, since the administration remains concentrated at the federal level and bases are identical - taxpayers will only have to fill one tax form. It also has the advantage of being levied on the basis of citizens' residence (as opposed to the payroll tax which is levied in the state of employment and to the sales tax which would be affected by cross-border shopping). However, the share of the economically active population currently paying the personal income tax is low, partly reflecting the skewed income distribution (see OECD, 2005d), combined with a high income threshold and tax reliefs, as well as a large informal sector. ${ }^{23}$ Thus, relying on a tax paid by a small share of local citizens may not serve much to promote states' accountability, unless reforms are implemented to increase the number of individuals paying income tax by broadening the base (e.g. through the removal of various special treatments).

25. International experience with sales taxes at the sub-national level is rather mixed. In the United States, sales taxes are the single most important form of own-revenue for states and are also of some importance for local governments; but the base has narrowed substantially, reflecting a shift in consumption patterns from goods towards services, many of which are exempt from the sales tax because services are predominantly sold to businesses. Avoiding cascading taxation of business purchases by exempting sales to producers should be an objective but it may result in high administrative costs and/or spur tax evasion. ${ }^{24}$ Revenue losses associated with cross-border trade and the development of e-commerce are also serious issues.

26. Using a consumption base for sub-national taxes still presents some advantages compared to a personal income tax surcharge. Revenues from consumption taxes tend to be less volatile over time - an important criterion for judging whether a tax base is appropriate for sub-national use. They may also be more evenly distributed across regions than income taxes. If the national authorities were to give significant weight to these two factors, a superior option to sales taxes would likely be to implement a dual

23. Progressivity in the federal personal income tax is rather low at the upper end of the income scale. Top statutory marginal rates have been reduced gradually, to $32 \%$ in 2005 , and are not high by OECD standards. Various rebates (e.g. exemptions for fringe benefits as well as the deductibility for medical expenses and contributions to private retirement schemes, see OECD, 2005d) further contribute to mitigate the actual progressivity at the upper end of the income scale. In this context, giving states the right to introduce a surcharge on the federal personal income tax is unlikely to create intense competition across states to attract the affluent.

24. Dividing sales between taxed and exempt at time of purchase - the retail sales tax approach - is more difficult than paying tax on all purchases and collecting taxes on all sales. See Díaz-Cayeros and McLure (2000) for a good discussion on the problems raised with the combination of a federal VAT and a state sales tax. 
VAT system. ${ }^{25}$ Experiences in Canada and within the European Union provide useful insights (Box 5). Among the large variety of models, the approach implemented in Quebec presents clear advantages for Mexico. The combination of a federal VAT (GST) with the provincial one in Quebec (QST) embodies a self-enforcement mechanism, provides sub-national governments with some autonomy to set rates, and avoids creating too large distortions in inter-jurisdiction trade.

\section{Box 5. Experience with decentralised VAT in Canada and within the EU area}

Sub-national taxes on consumption have been applied in a number of countries. In implementing sub-national VATs, however, some trade-offs between efficiency concerns and revenue-raising autonomy at the sub-national level have emerged. Key risks associated with sub-national VAT involve distortions in inter-jurisdiction trade, as well as higher tax evasion and tax compliance and collection costs. The Canadian and EU experiences shed light on how these issues have been dealt with, or remain unresolved.

Canada provides many useful insights for the design of decentralised consumption taxes since various models have been implemented. The dual provincial/federal VAT implemented in Quebec likely provides the best balance between the objective of raising sub-national government taxing powers, and thus accountability, and minimising inefficiencies associated with sub-national consumption taxes (see Bird and Gendron, 2001). ${ }^{1}$

A dual VAT system in Quebec. The province of Québec applies a VAT (somewhat confusingly called Quebec Sales Tax) on top of the federal government VAT (GST). The QST is administered by the provincial government which also administers the federal GST, thus avoiding duplication in compliance and collection costs. Taxes on interprovincial sales from one business to another are essentially handled using a deferred-payment system similar to that now applied in the EU, except that the overriding federal GST acts as an enforcement mechanism. Exports from Quebec, whether to another province or country, are zero-rated for QST purposes. Since exports to another province are subject to the federal GST, incentives to comply with the VAT system remain strong. The normal process of federal GST audit in effect further serves as a cross-check to ensure that the QST has not been evaded. In addition, since the QST is applied to a GST-inclusive base, Quebec has a direct incentive to monitor the GST as well as the QST.

The HST system in Newfoundland, Nova Scotia and New Brunswick. In 1997, an agreement between the federal government and three eastern provinces led to the introduction of a joint VAT (the HST), with one harmonised base and a combined federal-provincial rate of $15 \%$ in the three participating provinces. The HST replaced the federal value added tax (GST) in these provinces and the provinces' sales taxes. The HST is administered by the federal government. Revenues are shared on the basis of province-specific consumption patterns. Still the HST agreements limits provincial and federal government autonomy since the rate of the HST cannot be changed without a unanimous agreement.

The "transitional" VAT system within the European Union. The European Union has kept a dual system since 1993: the destination principle applies for the business sector, but the origin principle is implemented for most cross-border purchases by individuals (the main exceptions being purchases of new vehicles and mail order transactions). Such a dual system attempts to fulfil the requirements of an internal market without frontiers whilst allowing room for manoeuvre at the national level as regards the choice of VAT rates and the collection and auditing of the tax. The transitional regime replaced custom controls by the obligation, for all EU firms involved in distance selling to individuals (B2C) in another EU country, to register and account for VAT in that country on all those sales, once having passed a threshold of sales. Intra-EU business-to-business sales also have to be declared. Still, complexities of VAT procedures, combined with the lack of uniformity in the implementation of EC Directives on VAT across EU countries, have acted as a major disincentive to cross border trade and given rise to tax fraud (Joumard, 2001).

1. In addition, five provinces apply retail sales taxes (Ontario, Manitoba, Saskatchewan, British Columbia and Prince Edward Island), over and above the federal VAT. They administer their sales taxes independently from the federal GST, which does not apply to the same base.

25. Before moving to a dual VAT system, a reform to broaden the VAT base and improve tax collection would be most welcome. These efforts would also redress the VAT regressive bias, since the massive exemptions and zero-rating in the VAT system subsidise top income deciles more (OECD, 1999). 
27. Whether or not the reform should be revenue-neutral at the national level is also an important issue. If the increase in states' revenue-raising powers results from a transfer of a tax base from the federal to the state governments, as in 2005 , some downward adjustment in federal transfers (through the revenuesharing arrangement) would seem warranted. This would also increase the incentives for states to exercise their new taxing powers. At this juncture, the very low redistributive potential of the revenue-sharing arrangement in Mexico mitigates the equity concern associated with a shift in financing sources from federal transfers to own taxes. But an active Congress would certainly resist any reduction in federal transfers to states and municipalities. On the other hand, given the need to enhance permanent revenues in Mexico to finance core spending programmes such as basic education, health and poverty alleviation (see OECD, 2005d), states' taxing powers could be implemented without cutting commensurately the federal government tax revenues. ${ }^{26}$ Under this scenario, national tax revenues would increase and states should take clear responsibilities for the much needed additional public spending.

\section{Securing fiscal discipline in a decentralised setting}

28. Ensuring the sustainability of public finances while maintaining a stabilisation role for fiscal policy is an important challenge in the decentralised setting in Mexico.

\subsection{The volatility of sub-national government revenues distorts their spending behaviour}

29. Sub-national government revenues are highly volatile, creating a risk of a sub-optimal allocation of resources. Several federal grants are set as a fixed percentage of a basket of federal taxes and oil-related revenues. ${ }^{27}$ These grants accounted for $3.1 \%$ of GDP in 2004, but have fluctuated significantly over time (Figure 9). In addition, actual federal grants have differed in several instances from those projected in the federal government budget (e.g. to reflect higher or lower federal revenue, on account of oil price changes), which are used as a baseline by sub-national governments to drawing their own budgets. Although some ad-hoc smoothing has recently been allowed, this volatility makes budget planning at the sub-national government level difficult. ${ }^{28}$ Problems are particularly acute for grants earmarked for infrastructure development. ${ }^{29}$ Despite some flexibility in the timing of use for the PAFEF for 2004 and 2005 fiscal years,

26. Simulations by Webb and Gonzalez (2004) indicate that allowing states to introduce a $2 \%$ sales tax accompanied by a commensurate reduction in the federal VAT rate will only be attractive to most of the states if the federal government absorbs at least part of the costs (i.e. by cutting revenue-sharing transfers to the states by less than justified by the reduced VAT rate). If the federal government absorbed half of the cost, it would need to compensate only the Chiapas and Tabasco individually to have all states gain.

27. Federal transfers set as a share of tax and oil-related revenues include the so-called participaciones and several earmarked grants: the fund for municipal development (FFM), the Fund to strengthen municipal finance (FORTAMUN), the Fund to strengthen states' finance (PAFEF) and the Social Infrastructure Fund (FAIS). In addition, the Fund for infrastructure in the states (FIES) is set as a share of the oil windfall revenues (see chapter 4). In 2004, the share was set at 50\% and the FIES amounted to peso 23.3 billion. Issues arising from the assignment of oil revenues to sub-national governments are discussed in Ahmad and Mottu (2003) and in Brosio (2003).

28. In 2002, states faced lower-than-anticipated revenues following the 2001 recession. Given that states had committed some of their expected revenues to projects or items that could not easily be reversed during the final quarter of the year, the federal government decided to bring forward future income from the revenuesharing arrangement for 2003. Therefore, states were able to solve their liquidity problems and fulfilled their obligations in 2002. In principle, they would have had to face lower (but anticipated) income from the revenue sharing scheme in 2003. In practice, higher oil prices implied higher federal revenue to be shared.

29. In 2004, states used only $63 \%$ of the federal government grants earmarked for investment through the FIES. In six of them (Campeche, Coahuila, Nayarit, Querétaro, Jalisco and Tabasco), this percentage only reached one third or less (La Crónica, December 30, 2004). 
most other earmarked grants have to be spent within the fiscal term, impeding states from carrying over unused appropriations. This creates incentives for end-year spending sprees and likely results in poor costeffectiveness of public investment programmes.

30. The volatility of sub-national governments' resources may also result in a ratchet effect in spending. By nature, sub-national government current spending is largely unresponsive to the economic cycle, is difficult to cut, and even adjusts upwards during a downturn (e.g. with fewer people employed in the formal economy during a downturn, the number of uninsured persons and thus states' health spending will increase). In this context, easy-to-cut components (such as investment) suffer the most in a downturn while they may have a high social rate of return. ${ }^{30}$ On the other hand, public employment or wages may rise in an upturn and, because of the rigidities in public employment contracts, are difficult to prune thereafter. A ratchet effect on public spending may thus develop - requiring the federal government to adjust transfers to sub-national governments upward in difficult times, an adjustment which tends to become permanent. The introduction of the PAFEF in 2000 and the current proposal to institutionalise it provides a clear case.

\section{Figure 9. Volatility in federal transfers received by sub-national governments1}

Annual growth rate, 1993 prices

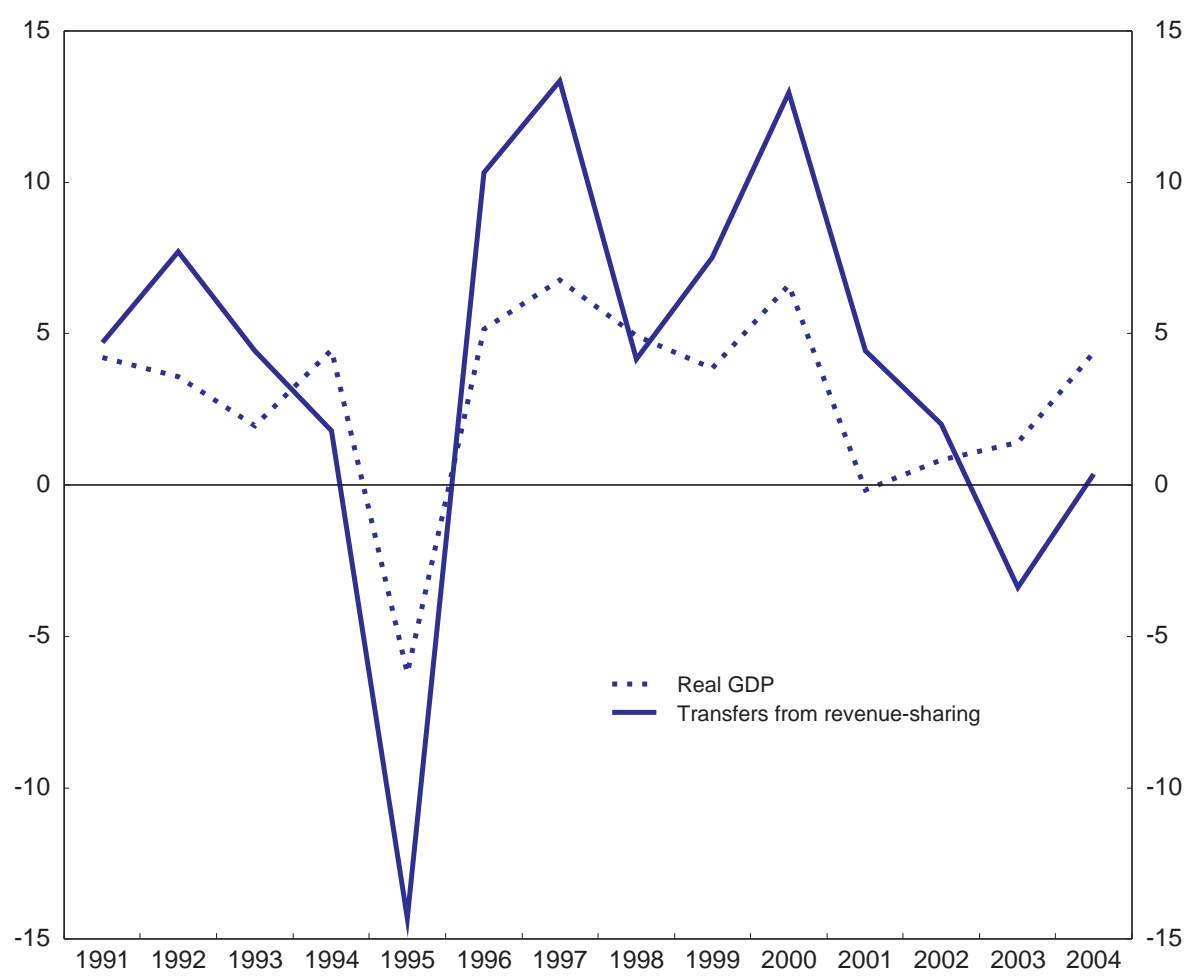

1. The main transfers shown here include resources from: the so-called General Participation Fund, the Contingency Reserve, the Municipal Development Fund, the special tax on products and services (IEPS), and the taxes on new and old cars (ISAN and Tenencia). Source: Ministry of Finance.

30. Partial indication suggests that at the state level, the share of current spending in total spending increased from 80 to $88 \%$ between 1994 and 2001 (Secretaría de Hacienda y Crédito Público, 2003). 


\subsection{Fiscal sustainability is not ensured in the longer term}

\subsubsection{States' debt has trended up again since 2000,...}

31. Although it increased in real terms in the early 2000s, states' debt is still low as a share of GDP (1.8\% in 2004) and by international standards ${ }^{31}$ Gauging financial sustainability at the state level would, however, require comparing their liabilities with the financial resources over which they have a direct leverage, i.e. their own revenues. At close to $200 \%$ in 2003, the debt-to-own revenues ratio for the states is very high, and significantly above the 1994 pre-crisis level (Figure 10). ${ }^{32}$ In addition, implicit liabilities stemming from pension systems for public employees are high in most states. They amounted to about $25 \%$ of GDP in 1998, according to the first Convención Nacional Hacendaria, despite recent reforms in some states (including Aguascalientes, Coahuila and Guanajuato) to put their pension systems on a sounder footing. ${ }^{33}$ Contingent debt associated with local public enterprises and sub-national governments' debt towards public utilities may also be sizeable ${ }^{34}$ although the federal government recently repaid part of subnational governments' debt towards water and electricity companies.

31. In Austria, Belgium, Canada and Spain, the debt-to-GDP ratio of the intermediate government tier stood at $3,6,46$ and $7 \%$, respectively, in 2003.

32. Reflecting a more limited access to borrowing, municipalities' financial position has likely remained under better control. According to Fitch (2002a), the overwhelming majority of municipalities in Mexico tend to have considerably lower debt levels relative to the states. On the other hand, Díaz Cayeros and MartínezUriate (1997) suggested that although there are few highly indebted municipalities in number, they concentrate a very important share of the population.

33. Existing pension systems also limit geographical and functional mobility of employees since pension rights are not portable when employees move from on state to another, even in a similar position, or take a private sector position.

IMF (2004). 
Figure 10. States' liabilities

Per cent
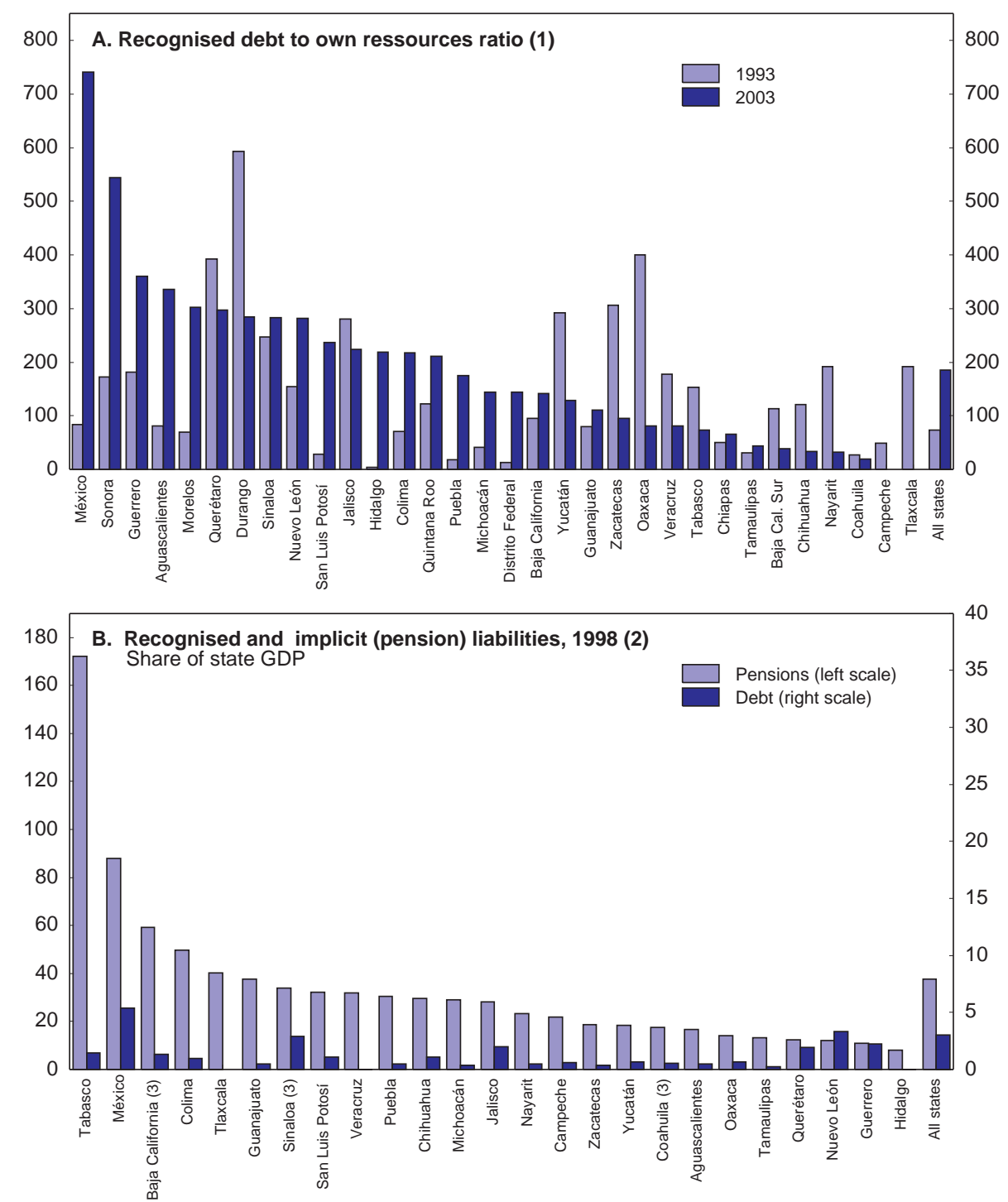

1. Own resources are the sum of states' own taxes and non-tax revenues.

2. Pension liabilities have been estimated as the sum of actuarial deficits of states' pension system for their own employees, taking a $3.5 \%$ actualisation rate.

3. Teachers and administrative services only.

Source: SHCP, Diagnóstico Integral de la Situación Actual de las Haciendas Públicas Estatales y Municipales (2005); INEGI, Finanzas Públicas Estatales y Municipales, 1999-2003; CEFP, Grado de Endeudamiento de las Entitades Federativas, al cierre de 2003. 
32. The generalised bail-out of the states by the federal government in the mid-1990s may well have undermined longer-term sustainability by creating a moral hazard problem. In the aftermath of the peso crisis, states' debt jumped from 1.3\% of GDP in 1993 to 2.2\% in 1995, reflecting the surge in interest rates. Since states were not able to service their debt, the federal government provided extraordinary cash transfers to the states of about $1 / 2$ per cent of GDP between 1995 and 1998 (IMF, 2004b). Such an intervention was reflected ceteris paribus in a reduction in states' debt but has also increased their capacity to borrow thereafter. ${ }^{35}$ In return for the debt takeover, states were required to commit to an adjustment programme with the Ministry of Finance, i.e. to balance their budget, to present their financial statements in a uniform way and to publish or update a debt law to regulate the dynamics of their own debt and that of the municipalities under their jurisdiction. By the end of 1995, all states had signed letters of intent with the federal government. However, no mechanism was in place to enforce these commitments. By 2002, only 9 states had introduced some limits on debt (often in the form of a ratio of debt to own revenues and revenue-sharing transfers or spending). ${ }^{36}$

\subsection{Instruments to secure fiscal discipline are weak}

\subsubsection{Fiscal rules imposed on sub-national governments are lenient}

33. Fiscal rules imposed on Mexican sub-national governments are rather loose compared with those in place in the majority of OECD countries. The federal Constitution states that sub-national governments can borrow only in peso, from domestic creditors, and for productive investment, but investment is not well-defined. New loans have to be approved by states' congresses. There is, however, no debt or deficit ceiling imposed by the federal government, either defined annually or over the medium-term. ${ }^{37}$ Such loose restrictions, combined with a heavy reliance on federal grants at the sub-national level, contrasts with the experience in many other OECD countries. In these, central governments that allow relatively unfettered access to credit markets are those that make sub-national governments fund a relatively large portion of their spending through own revenues (Rodden, 2004). Mexico also stands out as an exception in the OECD by combining loose constraints on sub-national borrowing with a scheme whereby federal transfers can be used as guarantee for sub-national governments' borrowing (Table 3).

35. It also raised equity issues since the size of per capita extraordinary transfers varied substantially across states, with richer states receiving overall more than poorer ones since they were more heavily indebted (Hernández Trillo et al., 2002).

36. The nine states with a formal limit on indebtedness are Campeche, Chiapas, Guanajuato, Hidalgo, Jalisco, Nayarit, San Luis Potosí, Tlaxcala, Zacatecas. See Secretaría de Hacienda y Crédito Público (2003) and Aregional.com (2002) for a description on fiscal rules in force in Mexican states. Besides quantitative limits, some state legislations include conditions on the maturity of the debt (e.g. Veracruz).

37. One complication in Mexico to design fiscal rules is the high sensitivity of public finance to oil price developments. The Chilean structural budget rule could, however, be a useful reference. Its main objective is to smooth public spending in a context of both cyclical fluctuations and copper price shocks so as to achieve more stable conditions for the implementation of long-term social and investment programmes (OECD, 2003b). Introducing a structural budget rule at the sub-national level may not be warranted and would, in any case, raise difficult issues. Still, the basic principles of this approach could be implemented to adjust over time federal transfers to sub-national governments. 
ECO/WKP(2005)40

Table 3. Strategies for ensuring fiscal discipline: fiscal rules and guarantees in selected countries

\begin{tabular}{l|cc}
\hline \multirow{2}{*}{ Limits on borrowing } & Central government's guarantees for sub-national governments' \\
borrowing
\end{tabular}

1. Sub-national governments can only borrow for investment and from Mexican investors (although investment is not well-defined). Federal transfers can be used as guarantee for sub-national governments' borrowing.

2. In the Netherlands the central government monitors closely municipalities' borrowing through a variety of instruments although there is no formal limit on borrowing.

Source: OECD/World Bank Budget Practices and Procedures database. 


\subsubsection{Recent reforms to strengthen the disciplining role of market mechanisms...}

34. Among the possible strategies to address the risks of a loose fiscal policy in a decentralised setting, priority in Mexico has recently been given to a market-oriented approach. The institutional setting governing sub-national government access to financial markets has been reformed since the late 1990s so as to promote the disciplining role of market mechanisms. This has entailed:

- Better information on sub-national governments' financial positions. To obtain access to credit markets, sub-national governments have now to be rated by two agencies. In this context, states and municipalities are required to provide public finance data for the last 10 and 5 years, respectively. By 2004, the 32 Mexican states and 75 municipalities were rated by at least one agency.

- Upgraded banking regulations so as to force lenders to account better for the risks associated with loans to sub-national governments. First, banking regulation for single-customer exposure limits has been extended to sub-national governments, reducing the attractiveness to creditors of sub-national governments lending. Second, banks' provision requirements have been made dependent on sub-national governments' credit ratings, with risk weights ranging from 20 to $150 \%$.

- Removal of the requirement to get federal government's approval for any new loan. Since 1997, sub-national governments are no longer required to get an approval for any new borrowing operation from the Ministry of Finance. ${ }^{38}$ They no longer need to register the debt with the Ministry of Finance (although unregistered loans would be automatically risk-weighted at $150 \%$ for lenders). As a counterpart, in case of arrears or a threat of default from one state, the federal government is no longer required to act as a lender of last resort (nor it is prevented from intervening) - banks could not ask the Ministry of Finance to discount the corresponding debtservice amount from a defaulting state's federal transfer (IMF, 2004).

\subsection{3 ... may not guarantee fiscal discipline}

35. The still poor quality of public finance data and the implicit federal government guarantee on sub-national government borrowing weaken the disciplining role of market mechanisms. Although the availability of information has improved since the late 1990s, partly as a result of the rating requirement above described, the lack of a well-established accounting framework on sub-national governments' existing liabilities and repayment capacity makes it difficult to assess and compare sub-national governments' financial positions. In particular, federal and state accounting records are still inconsistent, while the structure and information content of sub-national public accounts are heterogeneous. ${ }^{39}$ In addition, lenders can no longer ask the federal government to act as a trustee in servicing state debt, the recently created master trust fund arrangements (Fideicomiso maestro) to facilitate sub-national government access to the credit market have introduced a new scheme enabling federal transfers to be used as collateral for sub-national governments' borrowing (Box 6). These arrangements act to reduce incentives for lenders to discriminate against poor performing states. In practice, the rating assigned to these bond issues tends to be equivalent to those assigned to federal government issues in the domestic

38. According to Aregional.com (2002), this approval system allowed some discretionary decisions by the federal government.

39. For more information on this topic see the OECD Database on Budget Practices and Procedures, Aregional.com (2002) and the World Bank (2003). 
market (Fitch, 2004a). The competitive environment may further induce credit rating agencies to be overly positive when assessing sub-national government financial positions in order to keep clients. On the borrowing side, sub-national governments may expect that in case of serious financial difficulties impeding them to deliver core public services - some of which (e.g. health and education) are considered as a fundamental right for all citizens - the federal government would intervene. ${ }^{40}$ The special status of the Federal District, which continues to benefit from an explicit guarantee of the federal government, may reinforce these bail-out expectations.

\section{Box 6. Master trust arrangements to facilitate sub-national government access to financial markets}

In April 2000, a new scheme was implemented to facilitate sub-national governments' access to financial markets: the master trust fund (fideicomiso maestro). It allows issuers to pre-allocate future resource flows to a fund managed by a third party (the master trust fund), set up by sub-national governments and a bank (or a group of banks). The resources earmarked to these master trust funds consist in most cases of federal transfers (participaciones), and in some cases of payroll tax flows. These revenues are used to underwrite bond issues and/or bank loans. The fund redistributes federal transfers to sub-national governments after servicing the debt.

In 2004 , about $30 \%$ of the sub-national debt was backed by such master trust arrangements, with maturities between 5 to 15 years and grace periods of up to 6 years.

\section{An agenda for further reform}

36. Getting the most out of the decentralisation process would require improving the accountability of sub-national governments - by reaching a better balance between major responsibilities on the spending and borrowing side and rather limited revenue-raising powers - and better addressing disparities in regional development levels. Recommendations for moving in these directions are discussed below. Box 7 at the end of this paper provides a synopsis of these recommendations.

\subsection{Accompany greater sub-national government autonomy on the spending side by more accountability}

37. Several initiatives are required to spur sub-national governments' incentives to deliver high quality public services in a cost-effective way. A first priority should be to clarify the assignment, and reduce the overlapping, of spending responsibilities across levels of government. In some areas, sub-national government spending autonomy could be increased (e.g. in setting public employee job status and wage adjustments or in designing a larger share of the curriculum in the education sector). Responsibility for new infrastructure and for its maintenance should be kept at the same government level. Enhanced autonomy should be accompanied by reforms to strengthen pressures from citizens for more cost-effective services. Developing a coherent set of information allowing citizens to better understand how sub-national governments spend their resources and to gauge the outcomes of these programmes would contribute to this objective. The agreements reached at the Convención Nacional Hacendaria in 2004 - whereby sub-national governments committed themselves to provide information on their financial position in official documents and on their web pages - should be implemented swiftly. Better and comparable information would also facilitate the identification of best practices in designing and managing public spending programmes. In addition, auditing mechanism and co-ordination at the federal and subnational government levels should be improved, in particular for earmarked grants. Abolishing the no reelection rule or, at a minimum, lengthening the duration of local mandates would also help to promote the accountability of local government representatives while better checks and balances should be implemented to reduce the scope for corrupt practices.

40. The Mexican Constitution states that every citizen has the right to health care and education. 


\subsection{Reform the financing principles of sub-national governments}

38. The financing principles of sub-national governments should be reformed so as to promote subnational governments' accountability and to better address disparities in regional development levels. Increasing local government revenue-raising powers could help secure fiscal discipline by making the costs of local public services more visible for local taxpayers. Still, forcing sub-national governments to pay the political costs of their spending decisions by exercising their taxing powers would require ending the practice of raising federal transfers frequently and, often, on an ad-hoc basis. The choice of a "best sub-national tax" and its implementation still remains a delicate issue. At the municipal level, reliance on the property tax could be increased by reducing existing institutional barriers to its wider use. Upgrading the land register should be a priority and technical help from the federal government would be welcome for some municipalities. Transferring the responsibility of setting rates from the state legislatures to municipal governments is also desirable. At the state level, the current high reliance on payroll taxes is not a panacea and it does not serve much to improve accountability, since states' payroll taxes are deductible from federal taxes. Giving states a share of the federal personal income tax base has some merits - not least because it is visible and because additional collection and compliance costs can be contained. This option may, however, reinforce disparities in financial resources across states since personal income tax bases are highly concentrated geographically. A sub-national consumption tax would be preferable in this regard, although it may increase compliance and collection costs. To mitigate this, a dual VAT approach is preferable to the option which was proposed by the government - a state final consumption tax combined with a federal VAT.

39. Earmarked grants, whose amounts reflect historical costs, actual endowments and/or cyclical conditions, should be reformed. For the allocation of the basic education grant (FAEB), which is the main earmarked grant received by the states, moving from a formula driven by supply factors (number of schools and teachers) to one based on objective needs (number of school-age children) would be most welcome. It should be recognised, however, that such a shift cannot be implemented rapidly in the context of existing rigidities in public employees' job contracts. Consideration should be given to include the quality of education services in the formula. Allocation criteria for the grant to strengthen states' financial positions (PAFEF) should be clarified and designed so as to avoid moral hazard problems. Furthermore, it should be allocated, if at all, only for promoting states' efforts in reforming their public pension system toward a funded system, by covering part of the transitional adjustment costs - a similar reform is under discussion at the federal level for the ISSSTE system (see OECD, 2005d). In any case, a consistent strategy for reforming federal and sub-national pension systems should be developed. Otherwise, the PAFEF should be abolished. Merging some of the existing earmarked grants and implementing carry-over provisions to avoid end-year spending sprees could also help to improve their cost-effectiveness, in particular for those grants earmarked to infrastructure programmes.

40. Funding principles for sub-national government should also be reformed to address interregional disparities more effectively, in particular since a greater reliance on sub-national taxes could reinforce existing inequities in access to core public services. The shift in earmarked grant formula from supply- to demand-driven factors above recommended would already serve this purpose. Yet, the use of earmarked grants should be restricted to internalising clear spillover effects, and not to redistributing more to poorer jurisdictions. Embodying more fiscal equalisation into the existing revenue-sharing arrangement is difficult since states have an opt-out clause. Still, new block transfers to most deprived areas could be envisaged, financed by a combination of some cutbacks on earmarked grants and higher federal government revenues. The main grant earmarked to social infrastructure (FAIS), targeted to poor states and municipalities, should be reformed along these considerations and its effectiveness judged by reductions in the level of poverty. For public services with clear spillover effects (e.g. water provision and wastewater treatment facilities), an earmarked grant could continue to be used but the formula needs to be changed, so that a sub-national government using the federal money in an effective manner (such as improving access to water) does not 
face a cut in grant in the following period. Introducing a reward factor in the formula (for those improving basic services) is part of the solution. For other public services, a move from earmarked to block/equalising grant would be warranted.

\subsection{Maintain a stabilisation role for fiscal policy and promote fiscal sustainability}

41. The volatility of the financial resources made available to sub-national governments should be reduced so as to avoid ratchet effects in good times and higher federal transfers in difficult times. To this end, the formula used to derive the overall amount of revenue-sharing transfers and some of the earmarked grants should be modified in order to limit the impact of cyclical and oil price developments. This would avoid temporary increases in federal transfers being translated into permanent sub-national spending. Still, some of the recent increase in oil revenues has a persistent nature (although not necessarily permanent) and could be used to finance badly needed infrastructure, but not recurrent spending, at the sub-national government levels (e.g. in the water and transport sectors). In this context, federal grants earmarked to infrastructure could be set as a share of these persistent extra-revenues (see OECD, 2005d). This would avoid the stop-go approach to investment which has resulted in a poor cost-effectiveness of some public infrastructure programmes.

42. Market mechanisms and fiscal rules should be given a greater role in enhancing fiscal discipline. The use of federal government transfers as a guarantee for sub-national government borrowing needs to be restricted because of moral hazard problems. This could be achieved by setting a limit on the share of federal transfers which can be used to underwrite sub-national government borrowing and/or by making such an implicit guarantee conditional on sub-national governments implementing a prudent fiscal rule (such as a budget balance requirement or a limit on the debt service and/or total debt ratio). For fiscal rules and market mechanisms to play an effective role, information on sub-national governments' financial positions should be improved. This would require the federal government, in co-operation with subnational governments, to pursue its efforts to define a consistent and harmonised accounting framework, which would include information on implicit and contingent liabilities. The federal government may also need to provide technical assistance to help ensure its swift and effective implementation. 


\section{Box 7. Recommendations for improving fiscal relations across levels of government}

\section{Accompany enhanced autonomy by more accountability}

- Clarify the assignment of spending responsibilities across levels of governments and reduce overlaps.

- Improve information on how sub-national governments spend their resources and on the outcomes of their policies. Further develop exchange of experience carried out at a sub-national government level.

- Reconsider the no re-election rule or, at a minimum, lengthen the duration of the municipal mandate.

Reform the financing principles of sub-national governments

- Improve the incentives and framework conditions for the effective use of existing taxing powers of sub-national governments before transferring new ones. In particular, ad-hoc increase in federal transfers should be avoided.

- $\quad$ Give more taxing powers to sub-national governments to promote their accountability, while taking into consideration existing disparities in revenue-raising capacity and technical resources across jurisdictions. At the municipal level, upgrading the land register is a necessary condition to raise more tax revenues in a fair way and this may require technical assistance from higher government levels. States should be attributed at least one main tax, possibly substituting for the existing payroll tax. There are two main options: allowing for a further reliance on a surcharge on the federal personal income tax or implementing a dual VAT system. If states' payroll taxes are maintained, they should no longer be deductible from the federal corporate income tax base.

- $\quad$ Adjust the formulae for allocating earmarked grants across sub-national governments (in particular for basic education), taking better into account objective criteria instead of historical costs (e.g. number of teachers and schools) in distributing money across states. Redress the existing perverse incentives in the use of some earmarked grants (FAIS for social infrastructure, FAEB for education) by improving transparency on the use and outcomes of these grants, and by introducing more flexibility in the timing of the use of investment grants.

- $\quad$ Allocation criteria for the earmarked grant for the strengthening of states' financial position (PAFEF) should be clarified and money used strictly to foster the reform of state employees pension schemes.

- Consider transforming some earmarked grants into a new system of grants which would be general-purpose and equalising grants when spillover effects of public spending programmes cannot be clearly identified or sub-national government use of the grant cannot be monitored.

\section{Promote fiscal stability and sustainability}

- $\quad$ Reduce the volatility of federal government transfers by smoothing the impact of cyclical developments and/or oil prices.

- $\quad$ Limit the use of federal government transfer as a guarantee for sub-national government borrowing and promote the implementation of prudent fiscal rules at the sub-national level.

- $\quad$ Promote the publication of harmonised information on sub-national government financial positions, including implicit and contingent liabilities. 


\section{Bibliography}

Ahmad, E. and E. Mottu (2003), "Oil Revenue Assignments: Country Experiences and Issues" in Fiscal Policy Formulation and Implementation in Oil-Producing Countries, edited by Davies, Ossowski and Fedelino, IMF.

Alvarez, J. (2002), “Financing Education Infrastructure: An Examination of Mexico's Federalisation”, in Decentralisation and the Financing of Educational Facilities, OECD, Paris.

Aregional.com, (2002), "El marco jurídico de la deuda pública en las entidades federativas - un estudio comparativo", No. 5, May.

Bird, R.M. and P.-P. Gendron (2001), "VATs in Federal Countries: International Experience and Emerging Possibilities", Bulletin of the International Bureau of Fiscal Documentation, July.

Brosio, G. (2003), "Oil Revenue and Fiscal Federalism" in Fiscal Policy Formulation and Implementation in Oil-Producing Countries, edited by Davies, Ossowski and Fedelino, IMF.

Chiquiar Cikurel, D. (2002), “Why Mexico's Regional Income Convergence Broke Down”, Paper presented to the Conference on Spatial Inequalities in Latin America, Cholula, Mexico, November, www.wider.unu.edu/conference/conference-2002-5/conference-2002-5-papers/daniel-chiquiar\%20cikurel.pdf.

Díaz Cayeros, A. and J. Martínez-Uriate (1997), "Towards a Model of Budgetary Allocation and RevenueSharing in Mexico's Local Governments": paper prepared for delivery at the Latin American Studies Association (LASA) meeting, Guadalajara, Mexico, April, http://136.142.158.105/LASA97/diazcayeros.pdf

Díaz-Cayeros, A. and C.E. McLure (2000), "Tax Assignment”, in Achievements and Challenges of Fiscal Decentralisation: Lessons from Mexico, World Bank, www.bancomundial.org.mx/pdf/Chap4_TaxAssignment.pdf.

Fitch (2002), "Financing of Mexican States, Municipalities and Agencies: Alternatives and Strategies", www.fitchratings.com/corporate/reports/report.cfm?rpt id=137592\&sector flag $=5 \&$ marketsector $=1$ \&detail=1.

Guichard I. (2005), "The education challenge in Mexico: delivering good quality education to all", Economics Department Working Papers, No. 447, October.

Hernández Trillo, F., A. Díaz Cayeros and R. Gamboa González (2002), "Fiscal Decentralisation in Mexico: the Bailout Problem", Inter-American Development Bank Research Network Working paper, No. R-447, www.iadb.org/res/publications/pubfiles/pubR-447.pdf.

Hernández Trillo, F. and J.M. Torres Rojo (2004), "Definición de responsabilidades, rendición de cuentas y eficiencia presupuestaria en una federación: el caso mexicano", CIDE Working paper, No. 303, August. www.presupuestocide.org/documents/Folleto_completoa_quien.pdf.

Ibarra Salazar, J. and A. Varella Mollick (2004), "Dependencia financiera de los municipios mexicanos: determinantes regionales e institucionales", Comercio Exterior, Vol. 54, No. 8, August.

IMF (2004), "Mexico: Selected Issues", IMF Country Report, No. 04/418, http://www.imf.org/external/pubs/ft/scr/2004/cr04418.pdf 
Joumard, I. (2001), "Tax Systems in European Union Countries”, Economics Department Working Papers, No. 301, June.

Joumard, I. and P.M. Kongsrud (2003), "Fiscal Relations across Government Levels", Economics Department Working Papers, No. 375, December.

Joumard I. and C. Giorno (2005), "Getting the most out of public sector decentralisation in Spain", Economics Department Working Papers, No. 436, July.

Joumard I. and T. Yokoyama (2005), "Getting the most out of public sector decentralisation in Japan", Economics Department Working Papers, No. 416, January.

Mendoza Cota, E. and G. Martínez (2001), "Globalización y dinámica industrial en la frontera norte de México”, Comercio Exterior, Vol. 49, No. 9, pp. 795-806, September 1999.

Merino, G. (2001), "Federalismo fiscal: diagnóstico y propuestas", in Un agenda para las finanzas públicas en México, (special issue) Gaceta de Economía, Instituto Tecnológico Autónomo de México, March, www.itam.mx/eventos/publicaciones/geconomia/safp06merino.

Moreno Jaimes, C. (2001), "La descentralización del gasto en salud en México: une revisión de sus criterios de asignación", CIDE Working Paper, No. 95.

Moreno, L.C. (2003), "Fiscal Performance of Local Governments in Mexico: the Role of Federal Transfers", CIDE Working Paper, No. 127, www.presupuestocide.org/documentos/descentralizacion/DT\%20127.pdf.

Oates, W.E. (1999), “An Essay on Fiscal Federalism”, Journal of Economic Literature, Vol. 37, September.

OECD (1999), OECD Economic Surveys: Mexico, Paris.

OECD (2003), OECD Economic Surveys: Chile, Paris.

OECD (2005a), "Place-based policies for rural development - the Micro-regions strategy (Mexico)", study presented at the OECD Conference on Designing and Implementing Rural Development Policy, Oaxaca, Mexico 7-8 April 2005.

OECD (2005b), OECD Reviews of Health Care Systems - Mexico, Paris.

OECD (2005c), OECD Economic Surveys: Austria, Paris.

OECD (2005d), OECD Economic Surveys: Mexico, Paris.

Paqueo, V. and C. González (2003), “The Health Sector”, in Mexico - Southern States Development Strategy, World Bank Policy Notes.

Rodríguez-Pose, A. and J. Sánchez-Reaza (2002), "Economic polarisation through trade: the impact of trade liberalization on Mexico's regional growth", Paper presented at the Cornell/LSE/Wider Conference on spatial inequality and development, www.wider.unu.edu/conference/conference2002-2/papers/rodriguez-pose-sanchez-reaza.pdf.

Secretaría de Hacienda y Crédito Público (2003), "Diagnóstico integral de la situación actual de las haciendas públicas estatales y municipales", www.indetec.gob.mx/cnh/Interes/DocsInt/FPEyM.pdf.

Sour, L. (2004), "El sistema de transferencias federales en México - Premio o castigo para el esfuerzo fiscal de los gobiernos locales urbanos?", Gestión y Política pública, Vol. XIII, No. 3, www.gestionypoliticapublica.cide.edu/num_anteriores/Vol.XIII_NoIII_2dosem/LauraSour.pdf.

Spiezia V. (2003), “Measuring regional economies”, OECD Statistics Brief, No. 6, October 2003. 
ECO/WKP(2005)40

Webb, S.B. and C.Y. Gonzalez (2004), "Bargaining for a new fiscal pact in Mexico", World Bank Policy Research Working Paper, No. 3284, http://econ.worldbank.org/files/35467 wps3284.pdf. 


\section{WORKING PAPERS}

The full series of Economics Department Working Papers can be consulted at www.oecd.org/eco/Working_Papers/

452. Raising Greece's Potential Output Growth

(October 2005) Vassiliki Koutsogeorgopoulou and Helmut Ziegelschmidt

451. Product Market Competition and Economic Performance in Australia

(October 2005) Helmut Ziegelschmidt, Vassiliki Koutsogeorgopoulou, Simen Bjornerud and Michael Wise

450. House Prices and Inflation in the Euro Area

(October 2005) Boris Cournède

449. The EU's Single Market: At Your Service?

(October 2005) Line Vogt

448. Slovakia's introduction of a flat tax as part of wider economic reforms (October 2005) Anne-Marie Brook and Willi Leibfritz

447. The Education Challenge in Mexico: Delivering Good Quality Education to All (October 2005) Stéphanie Guichard

446. In Search of Efficiency: Improving Health Care in Hungary (October 2005) Alessandro Goglio

445. Hungarian Innovation Policy: What's the Best Way Forward? (October 2005) Philip Hemmings

444. The Challenges of EMU Accession Faced by Catch-Up Countries: A Slovak Republic Case Study (September 2005) Anne-Marie Brook

443. Getting better value for money from Sweden's healthcare system (September 2005) David Rae

442. How to reduce sickness absences in Sweden: lessons from international experience (September 2005) David Rae

441. The Labour Market Impact of Rapid Ageing of Government Employees: Some Illustrative Scenarios (September 2005) Jens Høj and Sylvie Toly

440. The New OECD International Trade Model (August 2005) Nigel Pain, Annabelle Mourougane, Franck Sédillot and Laurence Le Fouler

439. The French Tax system: Main characteristics, recent developments and some considerations for reform (July 2005) Willi Leibfritz and Paul O’Brien

438. The Effects of EMU on Structural Reforms in Labour and Product Markets (July 2005) Romain Duval and Jørgen Elmeskov

437. Product Market Competition andEconomic Performance in New Zealand (July 2005) Annabelle Mourougane and Michael Wise

436. Getting the Most out of Public Sector Decentralisation in Spain (July 2005) Isabelle Joumard and Claude Giorno 
435. Sources of Inflation Persistence in the Euro Area

(July 2005) Boris Cournède, Alexandra Janovskaia, Paul van den Noord

434. Measuring Cyclically-Adjusted Budget Balances for OECD Countries (July 2005) Nathalie Girouard and Christophe André

433. Product Market Competition and Economic Performance in the United Kingdom (June 2005) Maria Maher and Michael Wise

432. The Benefits of Liberalising Product Markets and Reducing Barriers to International Trade and Investment: the Case of the United States and the European Union (June 2005)

431. Boosting Growth through Greater Competition in Denmark (May 2005) Martin Jørgensen

430. Fifteen Years of Economic Reform in Russia: What Has Been Achieved: What Remains to be Done? (May 2005) Rudiger Ahrend and William Tompson

429. Assessing the OECD Job Strategy: Past Developments and Reforms (May 2005) Nicola Brandt, Jean-Marc Burniaux and Romain Duval

428. Ageing, Welfare Services and Municipalities in Finland (May 2005) Jens Lundsgaard

427. The Impact of Structural Policies on Trade-Related Adjustment and the Shift to Services (April 2005) Per Mathis Kongsrud and Isabelle Wanner

426. Product Market Competition and Economic Performance in Iceland (April 2005) Thomas Laubach and Michael Wise

425. Enhancing Brazil's Regulatory Framework for Network Industries: The Case of Electricity, Oil and Gas, and Water and Sanitation (April 2005) Edmar Almeida and Nanno Mulder

424. Education Attainment in Brazil: The Experience of FUNDEF (April 2005) Luiz de Mello and Mombert Hoppe

423. Estimating a Fiscal Reaction Function: The Case of Debt Sustainability in Brazil (April 2005) Luiz de Mello

422. Product Market Competition and Economic Performance in the Netherlands (April 2005) Maria Maher and Michael Wise

421. Product Market Competition and Economic Performance in Canada (April 2005) Maria Maher and Jay Shaffer

420. The Impact of Ageing on Demand, Factor Markets and Growth (April 2005) Joaquim Oliveira Martins, Frédéric Gonand, Pablo Antolin, Christine de la Maisonneuve and Kwang-Yeol Yoo.

419. Product Market Regulation in OECD Countries: 1998 to 2003 (February 2005) Paul Conway, Véronique Janod and Giuseppe Nicoletti

418. Reforming Turkey's Public Expenditure Management (February 2005) Rauf Gönenç, Willi Leibfritz and Erdal Yilmaz 
ECO/WKP(2005)40 